Florida State University College of Law

Scholarship Repository

Scholarly Publications

2005

\title{
What IS a Tragedy of the Commons? Overfishing and the Campaign Spending Problem
}

Shi-Ling Hsu

Florida State University College of Law

Follow this and additional works at: https://ir.law.fsu.edu/articles

Part of the Comparative and Foreign Law Commons, Election Law Commons, Environmental Law Commons, and the Law and Politics Commons

\section{Recommended Citation}

Shi-Ling Hsu, What IS a Tragedy of the Commons? Overfishing and the Campaign Spending Problem, 69 ALB. L. REV. 75 (2005),

Available at: https://ir.law.fsu.edu/articles/507

This Article is brought to you for free and open access by Scholarship Repository. It has been accepted for inclusion in Scholarly Publications by an authorized administrator of Scholarship Repository. For more information, please contact efarrell@law.fsu.edu. 


\title{
WHAT IS A TRAGEDY OF THE COMMONS? OVERFISHING AND THE CAMPAIGN SPENDING PROBLEM
}

\author{
Shi-Ling Hsu*
}

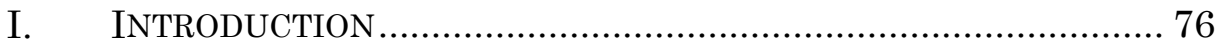

II. THE TRAGEDY OF THE COMMONS ………….......................... 78

A. Hardin's True Tragedy ..................................................... 78

B. Do Nothing? ................................................................... 89

C. Distinguished From Other Large-Group Externality

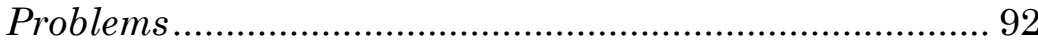

D. Other Examples of Tragedies of the Commons .................. 94

1. Traffic Congestion ...................................................... 95

2. Performance-enhancing Substances in Sports ........... 96

3. Informational Privacy ………………………............ 99

III. THE OVERFISHING PROBLEM.................................................. 100

IV. The CAMPaign Finance PRoBlem ………………............... 105

A. Overfishing for Votes ....................................................... 105

B. U.S. Federal Election Data............................................. 111

C. Is U.S. Campaign Spending "Excessive"? ....................... 121

V. Why Don’t Resource Users WANT to Be SAVEd From

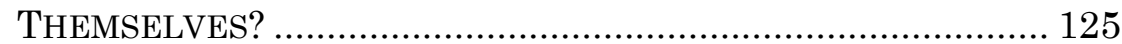

VI. SOlving TRAgEdies of THE Commons PRoblems ............... 131

VII. CONCLUSION .................................................................. 137

* Associate Professor of Law, University of British Columbia Faculty of Law. The author acknowledges the research assistance of David Madani and Nathan Muirhead, and the help and comments of Marty Smith, Dan Cole, and Kathy Baylis. Comments would be welcomed. 


\section{INTRODUCTION}

Over the thirty-seven years since its publication, Garrett Hardin's Tragedy of the Commons ${ }^{1}$ has clearly become one of the most influential writings of all time. The tragedy of the commons is one of those rare scholarly ideas that has had an enormous impact in academia ${ }^{2}$ and is also commonly used outside of academia. ${ }^{3}$ In legal scholarship, the tragedy of the commons has been used to characterize a scarcity of intellectual property rights, ${ }^{4}$ telemarketing, ${ }^{5}$ over-litigation of asbestos actions, ${ }^{6}$ neglect of Presidential papers, ${ }^{7}$ overcrowding of the radio spectrum, ${ }^{8}$ overcrowding of the wireless telecommunications spectrum, ${ }^{9}$ sidewalk vending, ${ }^{10}$ greenhouse gas emissions, ${ }^{11}$ water pollution, ${ }^{12}$

${ }^{1}$ Garrett Hardin, The Tragedy of the Commons, 162 SCIENCE 1243 (1968).

2 A Westlaw search on November 22, 2004 yielded 919 hits for "The Tragedy of the Commons,' /s Hardin." A search of the social sciences citation index on the same day produced 2,890 hits. Among the hundreds of books treating the concept in depth are: ELINOR Ostrom, Governing The Commons: The Evolution of Institutions for Collective Action (1990); Carol M. Rose, Property and Persuasion: Essays on the History, TheORY, AND RHETORIC OF OWNERSHIP (1994); LAWRENCE LESSIG, THE FUTURE OF IDEAS: THE Fate of the Commons in a ConNeCted World (2001); Commons Without Tragedy: Protecting the EnVironment from Overpopulation-A New ApProach (Robert V. Andelson ed., 1991).

3 A Google search on January 17, 2005 for "tragedy of the commons" yielded over 468,000 matches. Furthermore, a January 17, 2005 Westlaw search of the U.S. Congressional Testimony database yielded 32 hits, while a search of the Congressional Record database turned up ten hits, including an article by Scott Hodge entitled How Congress Forces Uncle Sam to Waste Money (submitted by Rep. Tom DeLay (R-Tex.)) which argues that political pork-barreling is a political tragedy of the commons. 136 CONG. REC. 16,175 (1990). Another hit was Sen. Charles Grassley (R-Iowa) stating that overuse of "fuel which enjoys hidden subsidies and external costs" is a tragedy of the commons. 137 CoNG. REC. 11,278-79 (1991).

${ }^{4}$ See Mark A. Lemley, Ex Ante versus Ex Post Justifications for Intellectual Property, 71 U. CHI. L. REv. 129, 141-42 (2004) (citing William M. Landes \& Richard A. Posner, Indefinitely Renewable Copyright, 70 U. CHI. L. REV. 471, 475 (2003)).

5 See Ian Ayres \& Matthew Funk, Marketing Privacy, 20 YALE J. ON REG. 77, 87 (2003).

6 See Francis E. McGovern, The Tragedy of the Asbestos Commons, 88 VA. L. REV. 1721, 1721-22 (2002).

7 See Jonathan Turley, Presidential Papers and Popular Government: The Convergence of Constitutional and Property Theory in Claims of Ownership and Control of Presidential Records, 88 CORNELL L. REV. 651, 715-17 (2003).

${ }^{8}$ See Karl M. Manheim \& Lawrence B. Solum, An Economic Analysis of Domain Name Policy, 25 Hastings Comm. \& ENT. L.J. 359, 416 (2003).

9 See Kevin Werbach, Supercommons: Toward a Unified Theory of Wireless Communication, 82 TEX. L. REV. 863, 935-37 (2004).

${ }_{10}$ See Gregg W. Kettles, Regulating Vending in the Sidewalk Commons, 77 TEMP. L. REV. 1, 3-4 (2004).

${ }_{11}$ See Roberta Mann, Waiting to Exhale?: Global Warming and Tax Policy, 51 AM. U. L. REV. 1135, 1144 (2002); Laura Kosloff \& Mark Trexler, State Climate Change Initiatives: Think Locally, Act Globally, 18 NAT. RESOURCES \& ENV'T 46, 46 (2004).

${ }_{12}$ See Richard J. Lazarus, Celebrating Tahoe-Sierra, 33 EnVTL. L. 1, 4-5 (2003). 
overdrafting of underground water, ${ }^{13}$ and of course, the classic environmental commons problem, overfishing. ${ }^{14}$

Remarkably, of the thousands of putative applications of the tragedy of the commons, not one has sought to formally define the term. In fact, this overabundance of citations highlights the fact that although we invoke it often, we do not know exactly what constitutes a tragedy of the commons. Hardin himself was most concerned with "exorciz[ing] the spirit of Adam Smith,"15 thus focusing his attack on the perils of unconstrained freedom. ${ }^{16}$ Extensive treatments of the tragedy of the commons have emphasized other key aspects of the tragedy, such as resource scarcity, ${ }^{17}$ free-rider problems, ${ }^{18}$ and lack of property rights. ${ }^{19}$ However, after nearly four decades of scholarly examination, no established formal definition has emerged.

Defining a tragedy of the commons is not simply an academic exercise. As I define it in this Article, a tragedy of the commons involves resource users overexploiting a resource and imposing mutual externalities upon each other. In true tragedies of the commons, Pareto Superior ${ }^{20}$ policy moves are possible in ways that are generally not feasible in other large-group externality problems, in which this self-destructiveness is absent. Saving the resource users from themselves and their mutually-imposed harms provides a paternalistic justification for intervention. This irony is what really animated Hardin's famous lament and is the most direct

${ }^{13}$ See David J. Hayes, Privatization and Control of U.S. Water Supplies, 18 NAT. RESOURCES \& ENV'T. 19, 23 (2003).

${ }^{14}$ See Jonathan H. Adler, Conservation Through Collusion: Antitrust as an Obstacle to Marine Resource Conservation, 61 WASH. \& LEE L. REV. 3, 9-10 (2004).

${ }_{15}$ Hardin, supra note 1, at 1244.

${ }^{16}$ Hardin's article is replete with signs of his disdain for the notion that more freedom is always better. His subheadings include "Tragedy of Freedom in a Commons," id.; "How To Legislate Temperance?," id. at 1245; "Freedom To Breed Is Intolerable," id. at 1246; "Mutual Coercion Mutually Agreed upon," id. at 1247; and "Recognition of Necessity," based upon Hardin's quote from Hegel: "Freedom is the recognition of necessity," id. at 1248. Hardin also criticized maritime nations for "respond[ing] automatically to the shibboleth of the "freedom of the seas," $i d$. at 1245 , and Western cattlemen for "constantly pressuring federal authorities to increase... [grazing limits] to the point where overgrazing produces erosion and weeddominance." Id.

${ }^{17}$ LESSIG, supra note 2, at 22.

${ }_{18}$ Ostrom, supra note 2 , at 6-7.

19 DANiel H. Cole, Pollution And Property: Comparing OWNership Institutions for ENVIRONMENTAL PROTECTION 6 (2002) ("It is the sociolegal fact of open access-the inability of any user or group of users to enforce their management decisions against any other user or group of users-that obstructs conservation of the resource.").

20 See generally Andreu Mas-Colell et AL., Microeconomic Theory 312-16 (1995). 
attack on Adam Smith's libertarian manifesto. ${ }^{21}$

Of course, in overexploiting a resource, resource users may also impose externalities upon a larger group that has some stake in the resource, such as the general public might have in clean air or water. This large-group externality alone may be sufficient justification for intervening, but a true tragedy of the commons specifically involves a situation in which the resource users are detracting from their own ability to continue to exploit the resource. Saving the resource users from themselves provides, independent of the need to internalize other large-group externalities, a particularly compelling case for governmental intervention.

I use the definition set forth in this Article to analyze a problem that has not been previously recognized as a tragedy of the commons - the problem of ever-increasing political campaign expenditures. In Part II of this Article, I set out my definition of a tragedy of the commons using the overfishing problem and other examples to illustrate what is unique about this class of problems. In so doing, I distinguish it from the broader set of large-group externality problems that are mischaracterized as tragedies of the commons problems, such as air and water pollution. In Part III, I use the overfishing problem to illustrate the dynamics of tragedies of the commons, showing how resource degradation over time impacts resource users. In Part IV, I apply this analysis to the problem of political campaign spending, showing how the problem is similar to the problem of overfishing, and showing how the current campaign spending debate, framed as freedom versus equality, is misguided. In Part V, I address the question of why those trapped in a tragedy of the commons are not more eager to address their joint overexploitation problem. Finally, in Part VI, I discuss solutions to tragedies of the commons, in particular those for the campaign spending problem.

\section{The TRAgedy OF THE COMMONS}

\section{A. Hardin's True Tragedy}

Hardin's tragedy of the commons has proven to be a worthy foil to Adam Smith's "invisible hand."22 Hardin's story of resource

\footnotetext{
${ }^{21}$ See infra Part II.A.

${ }^{22}$ Hardin, supra note 1, at 1244; George J. Stigler, Introduction to ADAM SMITH, Selections From the Wealth of Nations vii-ix (George J. Stigler ed., AHM Publ'g Corp.
} 
overexploitation poses a striking contrast to Smith's narrative illustrating the coincidence of self-interest and collective interest. Whereas Smith's lesson is that individuals acting in their selfinterest will act to increase collective wealth, ${ }^{23}$ Hardin's lesson is that individuals acting in their own self-interest will ruin collective wealth. $^{24}$ Consciously or not, all varieties of public policy are debated in ways that draw heavily upon at least one of these two concepts. Indeed, these two competing ideas, each based upon antithetical conceptions of the ability of people to order their own affairs, often serve as the underlying bases of arguments for and against governmental intervention. The "invisible hand" and the tragedy of the commons serve, in this policy realm, as the ideological beacons of libertarians and interventionists, those with opposing viewpoints of the appropriate role of government.

Whereas the implication of Smith's narrative is quite cleargovernment should intervene as little as possible - the implications of Hardin's tragedy are not. A variety of different policy prescriptions can cure the "commons" problem. ${ }^{25}$ In his article, Hardin called for "mutual coercion, mutually agreed upon." 26 But what does this mean? In the stylized examples provided by Hardin, a variety of interventions might be appropriate. To address the problem of pollution, some form of governmental pollution control

1957). Stigler characterizes Smith's concept as an "identity of interest" between self- and collective interests. Id. at vii.

${ }^{23}$ See Stigler, supra note 22, at viii. Smith's treatment of the division of labor, in which self-interested individuals agree to divide productive tasks to increase overall production, serves as one example of how self-interest can help produce increases in collective wealth. See Adam Smith, Selections From the Wealth of Nations 10-13 (George J. Stigler ed., AHM Publ'g Corp. 1957).

${ }^{24}$ Hardin, supra note 1 , at 1244 . Hardin details numerous examples of what he considers a tragedy of the commons, but most telling is his ultimate rationale for intervention: "mutual coercion, mutually agreed upon.” Id. at 1247.

25 Scholars have long noted that Hardin's "commons" problem is more powerfully applied in an "open access" setting, where no ownership rights exist at all, as distinguished from a common-pool resource. See, e.g., Carol M. Rose, Romans, Roads, and Romantic Creators: Traditions of Public Property in the Information Age, 66 LAW \& ConTEMP. PRoBs. 89, 93, 106 (2003) (finding that common-pool resources can limit overuse whereas "open access" resources are subject to overexploitation). The difference between a "commons" and "open access" is that a "commons" involves a resource that is jointly owned by a group of individuals who can exclude those outside the group, while "open access" is one in which there is no ownership or exclusion at all. Id.; COLE, supra note 19, at 15-16. A common-pool resource is thus one that can be considered as open access on the "inside" (within the group of joint owners) but private property on the "outside" (outside the group of joint owners). Rose, supra, at 106; Carol M. Rose, The Several Futures of Property: Of Cyberspace and Folk Tales, Emission Trades and Ecosystems, 83 MinN. L. REV. 129, 144 (1998).

26 Hardin, supra note 1 , at 1247. 
regulation may be called for. ${ }^{27}$ To address the overgrazing problem described in detail by Hardin, some limits to grazing are called for. ${ }^{28}$ But Hardin's message was not consistently interventionist. To address the overpopulation problem, ${ }^{29}$ Hardin seemed to prescribe the termination of some social programs that he considered to be subsidies for having more children. ${ }^{30}$ To address the overcrowding of national parks, Hardin suggested that privatization might be called for. ${ }^{31}$ Hardin's message was that something needed to be done, but he did not seem to distinguish between a governmental solution and a privatization solution, or the range of options in between. ${ }^{32}$

I suggest that Hardin's greatest contribution, the core insight of his article, is the identification of a class of problems in which there is a need to protect resource users from themselves, and to protect their own long-term access to the resource by limiting short-term access. This is the key to what scholars find most anomalous about the tragedy of the commons: the markedly illiberal notion that protecting resource users requires constraining their liberty in some way. This is how the tragedy of the commons can serve as the counter to the invisible hand-by representing the interventionist position. In Hardin's world, intervention is necessary because, despite the long-term futility of embarking upon the tragic course of overexploitation, people persist in doing so. ${ }^{33}$ If a tragic player

${ }^{27}$ See id. at 1245 (stating that taxes and laws which "make it cheaper for the polluter to treat his pollutants than to discharge them untreated" may be a means of addressing the tragedy of the commons involved in water pollution).

${ }_{28}$ See id. at 1245 (suggesting that cattlemen's failure to understand the concept of a tragedy of the commons leads them to pressure authorities to continually raise grazing limits to the point that erosion and weed dominance occur).

${ }^{29}$ See id. at 1243 (explaining that as population grows exponentially, the resources of a finite world are stretched thinner).

${ }^{30} I d$. at 1246.

If each human family were dependent only on its own resources; if the children of improvident parents starved to death; if, thus, overbreeding brought its own "punishment" to the germ line-then there would be no public interest in controlling the breeding of families. But our society is deeply committed to the welfare state, and hence is confronted with another aspect of the tragedy of the commons.

Id. (citation omitted).

31 Id. at 1245 .

32 Hardin's critics include those who maintain that often no intervention is necessary at all. For example, Coasians might argue that there is no principled basis upon which to intervene, since "injurers" or "victims" are mistaken constructs. R. H. Coase, The Problem of Social Cost, 3 J.L. \& ECON. 1, 2 (1960). Others, such as Ellickson, note that even in the face of transaction costs, people are often quite capable of ordering their own affairs by developing de facto property regimes independent of any governmental intervention. Robert C. Ellickson, Property in Land, 102 YALE L.J. 1315, 1386-87 (1993).

${ }^{33}$ Hardin, supra note 1, at 1244. 
could take a long-term view of resource exploitation or find a way to cooperate with fellow resource users-hardly heroic things to expect - the tragedy could be avoided. ${ }^{34}$ Yet for a variety of reasons, tragedies persist, ${ }^{35}$ particularly in environmental settings.

This formulation of the tragedy of the commons can be distinguished from the broader class of large-group externality problems in which resource users impose externalities upon a larger population, without necessarily harming themselves in the process. This historical confusion exists because in both types of problems the overexploitation pertains to jointly-owned or unowned resources. ${ }^{36}$ These ill-defined property regimes serve as the root cause of overexploitation. But Hardin's prescription of "mutual coercion, mutually agreed upon" 37 seems oriented toward solving problems within the resource user group and not necessarily (but often) on alleviating externalities imposed upon those outside of the user group. Furthermore, Hardin's examples of the tragedy of the commons-overpopulation, overcrowding of national parks, even bank-robbing-are most useful for illustrating the human propensity not simply to spoil something for everybody, but to spoil something for themselves.

What then is a "true" tragedy of the commons? I suggest that a truly tragic resource overexploitation, or a true tragedy of the commons, contains all of the following elements:

(1) Mutual, uninternalized externalities. A tragedy of the commons involves, if not perfectly symmetrical situations among identical players, at least a mutuality of externalities. The mutuality of externality places parties in mirroring situations in which every player knows that attempts at cooperative behavior will be met with cheating, and that every player knows that every player knows this. Knowing that even if one refrains from cheating others will cheat creates irresistible incentives to cheat.

\footnotetext{
34 See generally OSTROM, supra note 2, at 88-102 (examining the conditions under which cooperative arrangements, formal and informal, can solve common-pool resource problems).

${ }^{35}$ There are two broad classes of reasons why tragedies persist even in the presence of enormous incentives to cooperate: (i) transaction costs and (ii) behavioral anomalies. The literature on transaction costs as a barrier to cooperative behavior is voluminous and wellestablished, beginning with Harold Demsetz, Toward a Theory of Property Rights, 57 AM. ECON. REV. 347, 354-55 (1967) and OstRom, supra note 2, at 190-91. A review of the more recent literature on behavioral anomalies that confound solutions to the tragedies of the commons can be found in Barton H. Thompson, Jr., Tragically Difficult: The Obstacles to Governing the Commons, 30 ENVTL. L. 241 (2000).

${ }^{36}$ More broadly, the overexploitation exists because of an improper property definition. COLE, supra note 19 , at 4.

${ }^{37}$ Hardin, supra note 1, at 1247.
} 
(2) Group payoffs that are less in uncooperative outcomes than they are in cooperative ones. The tragedy of the commons must be distinguished from distributive questions. If uncooperative behavior merely leads to a wealth transfer without any loss of overall welfare, then there is not necessarily any efficiency loss suffered from the societal point of view. ${ }^{38}$ A "tragedy" implies a loss.

(3) A resource that is rivalrous in consumption. While situations involving nonrival goods may also produce incentives for uncooperative behavior, rivalrous consumption among those in a competitive environment creates particularly strong incentives to cheat. The understanding that consumption by others detracts from one's own consumption, coupled with the mutuality of externalities and the knowledge that this will likely lead to cheating by others, is what gives rise to the inevitability of uncooperative behavior.

A game-theoretic illustration may be helpful to demonstrate the logic of tragic behavior, and an economic explanation of why the tragedy can be so persistent. Consider a game involving two fishermen, A and B, that will last for 100 time periods, with A moving in periods $1,3,5, \ldots 99$, and $\mathrm{B}$ moving in periods $2,4,6, \ldots$ 100. The fishery is assumed to have a capacity to sustainably yield 100 fish caught per period. That is, if A and B catch more than 100 fish in any period, the stock will be depleted and the capacity will fall to 99 for the following period and for all periods thereafter. Thus, if A and B could reach an agreement and honor it, they could sustainably harvest 100 fish per period for the entire 100 periods. As a baseline, assume that A and B would evenly split the 100 fish each period, and harvest 50 each. In any period, A or B could "cheat" and fish harder to catch an extra fish, or could "abstain" and maintain a current level and effort of fishing. It is further assumed that the effort from fishing is of negligible cost to these fishermen. That is, the gain of catching extra fish is of paramount consideration.

If, in time period one, $\mathrm{T}_{1}, \mathrm{~A}$ abstains from cheating and in time period two, $\mathrm{T}_{2}$, B decides to cheat, $\mathrm{B}$ will gain an extra fish for $\mathrm{T}_{2}$. A will have harvested 50 fish and $\mathrm{B} 51$ fish, yielding 101 fish in $\mathrm{T}_{2}$, but reducing the harvest capacity to 99 for $\mathrm{T}_{3}$ and all periods thereafter. Assuming B maintains the higher fishing effort for the remainder of the game, it is reasonable to assume that in future time periods, A and B will divide the 99 fish by harvesting 49 and 50, respectively.

\footnotetext{
38 See Lee Anne Fennell, Common Interest Tragedies, 98 Nw. U. L. REV. 907, 921 (2004).
} 
The net result for the entire game would thus be that $B$ will have gained one fish, and A, by losing out on one fish for each of the rest of the 98 periods, will have lost 98 fish, net of her baseline of 50 fish per period. If $\mathrm{A}$ does not retaliate by cheating but rather abstains, the game can be represented by Figure 1 and the payoffs by Table 1 .

FIGURE 1

Payoffs $\{A, B\}$

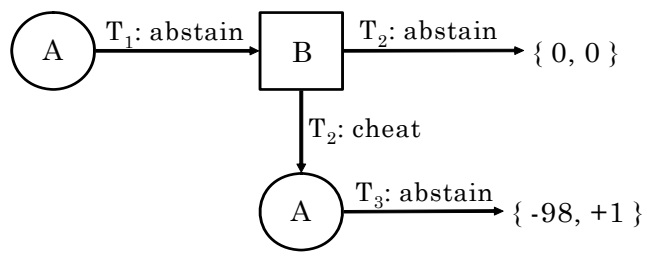

TABLE 1

\begin{tabular}{|l|l|l|}
\hline $\mathbf{T}$ & $\mathbf{A}$ & $\mathbf{B}$ \\
\hline $\mathbf{1}$ & 50 & 50 \\
\hline $\mathbf{2}$ & 50 & 51 \\
\hline $\mathbf{3 - 1 0 0}$ & 49 & 50 \\
\hline
\end{tabular}

It is reasonable to assume, however, that $\mathrm{A}$ would retaliate. In fact, it would be perfectly rational for $\mathrm{A}$ to do so. If $\mathrm{A}$ chose, in $\mathrm{T}_{3}$, to retaliate by fishing harder as well, she would also net an extra fish-50 instead of 49, and by both of them catching a total of 100 fish in $\mathrm{T}_{3}$, in an environment in which the yield capacity is 99 , A would play her part in reducing the capacity in $\mathrm{T}_{4}$ and subsequent time periods to 98 . In $\mathrm{T}_{4}$ and subsequent time periods, assuming that $\mathrm{A}$ and $\mathrm{B}$ fish equally hard, and assuming $\mathrm{B}$ abstains from further cheating, it is reasonable to assume that they would split the catch at 49 fish apiece. This game is shown in Figure 2 and the payoffs in Table 2 . 
FiguRE 2

Payoffs $\{A, B\}$

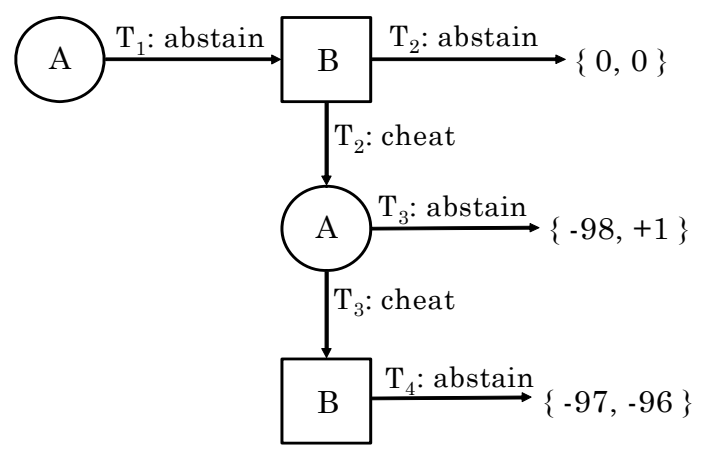

TABLE 2

\begin{tabular}{|l|l|l|}
\hline $\mathbf{T}$ & $\mathbf{A}$ & $\mathbf{B}$ \\
\hline $\mathbf{1}$ & 50 & 50 \\
\hline $\mathbf{2}$ & 50 & 51 \\
\hline $\mathbf{3}$ & 50 & 50 \\
\hline $\mathbf{4 - 1 0 0}$ & 49 & 49 \\
\hline
\end{tabular}

In this outcome, A's payoff would be less by one fish for the remaining 97 periods, resulting in a net payoff of -97 , relative to her baseline of 50 fish per period. B's payoff would also reflect this reduced payoff, but $\mathrm{B}$ benefited by cheating early on and catching an extra fish in $\mathrm{T}_{1}$. B's net payoff is thus -96, relative to her baseline, one more than A's. Although A has embarked upon the path to mutually tragic overexploitation, A is better off cheating as compared to the "abstain" strategy. Because of B's cheating, A was going to settle for 49 fish per year. By catching an extra fish in $\mathrm{T}_{3}$, A at least obtained an extra fish in $\mathrm{T}_{3}$, making her payoff less negative, -97 instead of -98 . This can be seen by examining the last two branches of the game tree in Figure 2 (A's payoff is the first number in brackets). If $\mathrm{B}$ chooses to abstain from further cheating, 
B will, despite her elevated effort, also catch one less fish for the remaining 96 periods. This is the penalty absorbed by A and B for fishing too hard and reducing the fishery's carrying capacity.

The game is likely to descend further, however. At $\mathrm{T}_{4}, \mathrm{~B}$ may not abstain and may well decide that she is not ready to settle for harvesting only 49 fish per year. The same calculus applies in $\mathrm{T}_{4}$ as in $\mathrm{T}_{2}$ : $\mathrm{B}$ can gain an extra fish by fishing a little harder, still catching 50 fish in $\mathrm{T}_{4}$. Even though the yield capacity will be further reduced to 97 (by virtue of A and B catching a total of 99 fish in an environment in which the capacity is 98 ), B will nevertheless realize a temporary, one-period gain of one fish. For the remainder of the game, B will be fishing harder still just to catch 49 fish per period, but under the assumption that fishing effort is costless, B will be better off for her single extra fish for one time period only. Because B is fishing harder than A, it is reasonable to assume that A and B will split the catch at 48 and 49 fish, respectively. B will thus have a game-total net of -95 (a loss of one fish for the remainder of the 95 periods plus the extra fish caught in $\mathrm{T}_{2}$ ), a better outcome than the final outcome in Figure 2, in which her net was -96. A, in the meantime, will suffer a loss of two fish every period for periods 5 through 100, and a loss of one fish in $\mathrm{T}_{4}$, for a game-total of -193 below her original cooperative baseline of 50 per period.

What next? At $\mathrm{T}_{5}$, A will retaliate by fishing still harder as well. Of course, A realizes that this is ultimately a fool's errand, but A realizes that she can at least snare an extra fish for one year by fishing harder. The yield capacity will be reduced to 96 , which will be split by $\mathrm{A}$ and $\mathrm{B}$ at 48 fish apiece, given their equally hard fishing efforts (assuming B abstains from further cheating). But A was going to settle for 48 fish per year, so she reasons that she might as well get the extra fish this year, and by snaring an extra fish in $\mathrm{T}_{5}$, A at least improves from -193 to -192 . The outcome is shown in Figure 3, and the resulting payoffs in Table 3. 
FiguRE 3

Payoffs $\{A, B\}$

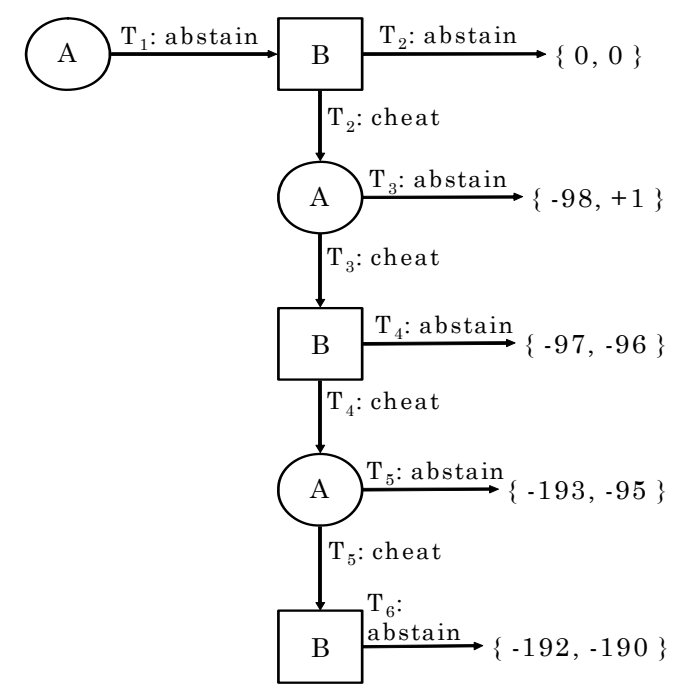

TABLE 3

\begin{tabular}{|l|l|l|}
\hline $\mathbf{T}$ & $\mathbf{A}$ & $\mathbf{B}$ \\
\hline $\mathbf{1}$ & 50 & 50 \\
\hline $\mathbf{2}$ & 50 & 51 \\
\hline $\mathbf{3}$ & 50 & 50 \\
\hline $\mathbf{4}$ & 49 & 50 \\
\hline $\mathbf{5}$ & 49 & 49 \\
\hline $\mathbf{6 - 1 0 0}$ & 48 & 48 \\
\hline
\end{tabular}

Several interesting things about Figure 3 are worth noting. First, it is an extensive-form representation ${ }^{39}$ of the tragedy of the commons, as opposed to the traditional one-period normal-form

39 See, e.g., MAS-COLELl ET AL., supra note 20, at 221-28 (1995); ROBERT GIBBONS, GAME THEORY FOR APPLIED ECONOMISTS 115-16 (1992). 
representation. ${ }^{40}$ Second, while the miniscule private gains are swamped by the huge social losses, from an individual's point of view, it remains rational to pursue the tragic path. At each decision node, it pays to cheat rather than abstain. The mutual externalities remain uninternalized. Finally, A's reward for abstaining in $\mathrm{T}_{1}$ was to suffer an inferior payoff to B in every time period. Thus, there is not only a disincentive to abstain, but a compelling incentive to cheat, and cheat first. The compelling incentive to cheat is not simply the miniscule gain of one fish in one time period, but the realization that abstention will be met with cheating. Herein lies the inevitability of the tragedy: the incentives to cheat are irresistible. They are irresistible because of the symmetrical nature of the externalities, and the mutual realizations that any abstention will be punished, and the realization that the other player understands that her abstention will be punished.

The solution to the tragedy of the commons, as many have noted, is cooperation. ${ }^{41}$ In the above game, the gains from cooperation would swamp those of adopting a cheating strategy. Professor Elinor Ostrom's seminal work on cooperative arrangements identified a number of sustainably-harvested common-pool resources, sometimes managed and exploited by fairly large groups. $^{42}$ However, cooperation takes place only if the resource users can overcome the transaction costs of cooperation, costs which can be daunting even in small groups and rise exponentially with the number of resource users. ${ }^{43}$

Even a casual review of the world's environmental problems reveals the difficulty of overcoming the transaction cost problem. The problem of constraining emissions of greenhouse gases that induce global climate changes has, over the thirteen years since formal recognition of the severity of the problem, ${ }^{44}$ made only

40 GIBBONS, supra note 39, at 27-29, 126-27 (describing the tragedy of the commons as a mathematical sequence of single or first order decisions).

${ }^{41}$ See, e.g., OSTROM, supra note 2, at 15-17 (using as an example a group of herders who make contracts among themselves and monitor each other to make the most efficient use of grazing land).

42 OSTROM, supra note 2, at 61-65 (high mountain forest communities in Switzerland); id. at 65-69 (forest communities in Japan); id. at 69-82 (irrigation districts in Spain); id. at 8288 (irrigation districts in the Philippines).

${ }_{43}$ See id. at 60-61 (observing that if transaction costs for communal management were excessive, the community members may choose different management arrangements); $i d$. at 224 n.2 (noting the observation that negotiating costs for communal arrangements may be large and include the policing of the agreement).

${ }_{44}$ The signing of the United Nations Framework Convention on Climate Change marked the beginning of formal international legal efforts to bring about an international regime for 
halting progress towards even a modest step, the Kyoto Protocol, ${ }^{45}$ which has been spurned by the largest emitter, the United States. ${ }^{46}$ International gamesmanship has clearly foiled even this massive effort to solve perhaps the most pressing and serious of environmental problems.

Similarly, the problem of rapid overdrafting of groundwater from the Ogallala Aquifer, the dominant source of water for the agricultural Midwestern United States, has been recognized for decades. ${ }^{47}$ As the largest aquifer in the world, the Ogallala could, if managed properly, sustain the American agricultural Midwest in near-perpetuity. ${ }^{48}$ What has been done about it? While all the states using the aquifer have some form of groundwater overdrafting regulations, ${ }^{49}$ their effectiveness is severely curtailed by the fact that Texas, the largest extractor of the Ogallala Aquifer, ${ }^{50}$ still has the common law "rule of capture" governing groundwater withdrawals. ${ }^{51}$

The abundance of other examples makes it clear that Ostrom's work, which identified the conditions that must exist for cooperation to take hold and arrest the tragic behavior, only emphasizes the uniqueness of the situations in which the conditions are met, and the reality that failures remain the rule, successes the exception. ${ }^{52}$

In addition to the transaction cost problem, a second class of obstacles to cooperation has been identified. Explanations for pathologies that have hindered cooperation have emerged from the

regulating greenhouse gas emissions that may result in global climate change. United Nations Conference on Environment and Development: Framework Convention on Climate Change, done May 9, 1992, 31 I.L.M. 849.

${ }_{45}$ See Conference of the Parties to the Framework Convention on Climate Change: Kyoto Protocol, Dec. 10, 1997, 37 I.L.M. 22.

${ }_{46}$ Alan Cowell, Summit Leaders Still Differ and Protesters Still Protest, N.Y. TIMES, July 5, 2005, at A6.

47 Marc Reisner, CAdillac Desert: The American West and Its Disappearing Water 455 (1986) ("It is a dead certainty that the Ogallala will begin to give out relatively soon; the only question is when.").

${ }_{48}$ See id. at 457 (concluding that the Ogallala Aquifer could have been "made to last hundreds of years instead of decades").

${ }^{49}$ See id. at 455 (noting that "all . . . states regulate the pumping of groundwater").

${ }^{50} \mathrm{Id}$.

51 Sipriano v. Great Spring Waters of Am., Inc., 1 S.W.3d 75, 75-80 (Tex. 1999) (holding that a landowner may withdraw as much water from beneath their land as desired without incurring liability from neighbors who may be injured by such a withdrawal). But see id. at 77-78 (noting that the legislature retained the power to regulate water use even within the framework of the rule of capture).

${ }_{52}$ OsTROM, supra note 2, at 88-102 (analyzing eight similarities among those commonpool resources that have been managed and harvested sustainably despite the lack of property ownership). 
behavioral psychology literature. These pathologies include selfserving perceptions of entitlement and fairness, ${ }^{53}$ myopia in interpreting uncertainty, ${ }^{54}$ reluctance to agree on burden-sharing, ${ }^{55}$ and endowment effects that reinforce the status quo. ${ }^{56} \mathrm{~A}$ more detailed discussion of these pathologies is set forth in Part V.

A true tragedy of the commons is thus the existence of a dynamic in which resource users overexploit a resource that is rivalrous in consumption so that they jointly reduce the long-term potential for exploitation. The tragedy lies in the way that resource users contribute to their own ruin by engaging in selfish behavior.

\section{B. Do Nothing?}

There is the objection that the assumption in the illustrative game above, namely that fishing effort is negligible compared with the harvesting gains, is at a certain point, unrealistic. As fishing effort increases, the cost of effort is likely to increase and the benefits likely to decrease, due to diminishing returns. At some point, it becomes unprofitable to overexploit, or to exploit at all, thereby putting an end to the cycle of overexploitation. Thus, the solution that suggests itself is to do nothing and allow the overexploitation to run its course, at which time the resource users will voluntarily cease. Given the futility of many interventionist attempts to solve tragedies of the common in the past, this solution has merit in some circumstances. However, the level of exploitation at which profitability disappears completely is apt to be at a level of harvesting that is sub-optimally high.

To illustrate this last point, consider the example of a fishery, shown in Figure 4, in which the marginal benefits and average benefits of exploitation decrease as harvesting level increases. We can assume constant marginal and average costs without loss of generality. The optimal harvesting level is $q_{o}$, the point at which marginal benefits equal marginal costs. However, as long as there are no entry barriers-as there would be if there were private ownership of the fishery or some entry restrictions-capital will

\footnotetext{
53 See Thompson, supra note 35, at 256, 260.

54 See id. at 262 (detailing the tendency of humans to be short-sighted as to the consequences of actions, especially in the commons dilemma and when there is uncertainty).

${ }_{55}$ See id. at $260,262$.

56 See Richard Thaler, Toward a Positive Theory of Consumer Choice, 1 J. EcON. BEHAV. \& ORG. 39, 44 (1980) (defining the "endowment effect" as the propensity for people to hold onto what they already have).
} 
enter as long as there are non-zero rents to be had, and will dissipate total (industry-wide) rents by increasing overall harvesting.

FIGURE 4

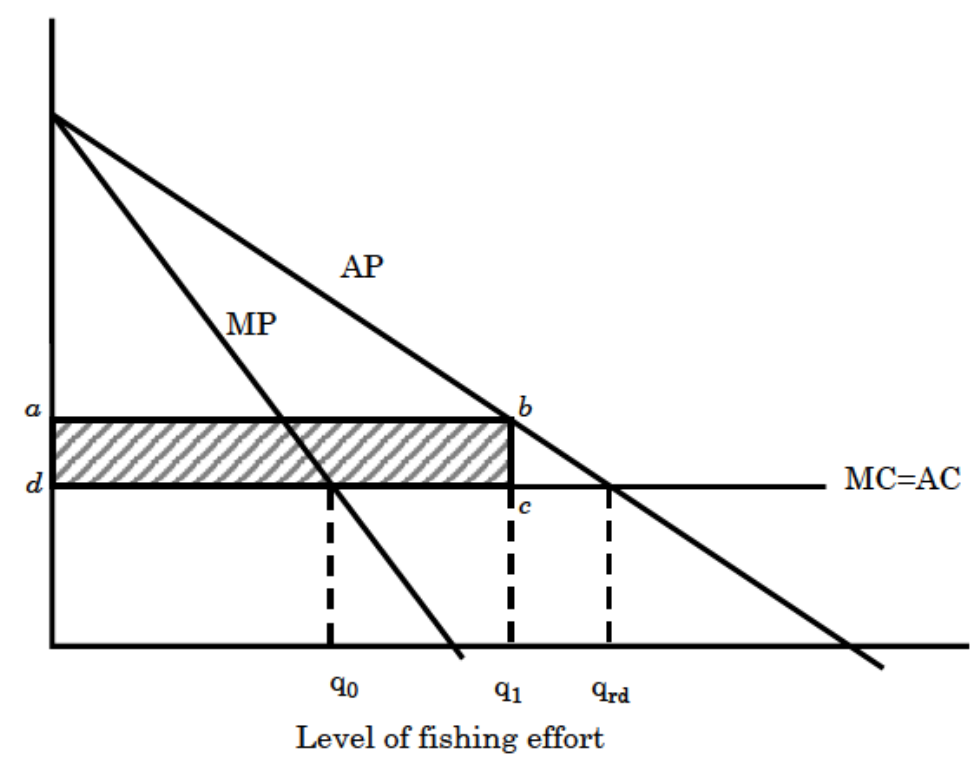

One such inefficiently high level of harvesting might be $q_{1}$, at which marginal benefits have sunk below marginal costs but rents still exist in the form of rectangle abcd, inducing more capital to enter. Economic models of overfishing have demonstrated that for an open access resource such as an unowned fishery, capital will continue to enter and overharvesting will continue to increase until a stopping point is reached, well beyond the optimum harvest level. ${ }^{57}$ At this point of "rent dissipation," $q_{r d}$ in the graph, the marginal benefit is well below the marginal cost. In this situation, the average cost is just equal to the marginal cost, and rents are zero. ${ }^{58}$ Herein lies the tragedy of the overfishing commons: fishermen literally fish themselves into poverty. ${ }^{59}$

One possible regulatory strategy would thus be to do nothing-to

${ }^{57}$ H. Scott Gordon, The Economic Theory of a Common-Property Resource: The Fishery, 62 J. PoL. Econ. 124, 130-32 (1954).

${ }_{58}$ Id. at $131-32$

59 Id. at 132 . 
give up on solving the tragedy of the commons and allow the situation to deteriorate to the point of rent dissipation. Such a course would in effect be a determination that rent dissipation is a lesser evil than an inappropriate regulatory response. At the point of rent dissipation, at least, the fish will get a break. This may be a plausible approach for some tragedy of the commons problems. For example, problems that truly are intractable, for which any regulatory response or property rights solution would be truly abhorrent or unworkable, this may be the answer. Some fisheries which are particularly difficult to police fall under this category. ${ }^{60}$ It could also be that the plundered resource is a resilient one such that any respite from overexploitation will allow it to quickly bounce back to healthy levels. ${ }^{61}$ It may also be that the capital used in exploiting a resource is a flexible one that exits the industry easily, avoiding the danger that the capital will get locked into the resource and irreparably overexploit it. ${ }^{62}$

However, for many, if not most, tragedy of the commons problems, such a let-the-chips-fall-where-they-may approach is clearly inadequate. The problem is that irreparable harm may have already occurred at the rent dissipation level. In the fishing example, it is possible that rent dissipation may not occur until the fish stock has crashed to the point that it is driven to extinction or will never recover. Obviously and most importantly, the economic harm to the resource users is usually not our only concern. Resource overexploitation usually imposes externalities upon the rest of the world. In this way, the loss of a fish species will invariably upset ecological balances in ways that are impossible to

${ }^{60}$ Cf. Thompson, supra note 35, at 245 (noting the difficulty of enforcing agreed-upon regulation in complex commons dilemmas, such as world fisheries). For example, Thompson notes that the human propensity to assign blame to others makes it difficult to get resource users to agree on anything. See id. at 260-62. New England fishermen blame the decline of blue fin tuna on Gulf of Mexico fishermen, who in turn blame it on Mediterranean fishermen, who in turn blame it on New Englanders. Id. at 261.

${ }^{61}$ Paterson and Wilen showed that where the exploited resource is resilient-in other words, where it bounces back from depletion quickly-the danger of irreversible overexploitation is low. See D.G. Paterson \& J. Wilen, Depletion and Diplomacy: The North Pacific Seal Hunt, 1886-1910, 2 RES. ECON. HIST. 81, 121-25 (1977).

${ }_{62}$ Also, where capital exits and enters the fishery quickly and easily, there is less danger that capital will have to rely solely on the fishery for income. Once the stock is depleted enough to render exploitation unprofitable, the fishermen will exit the fishery, concentrate on another, more profitable species, and return only when the stock is healthy enough to exploit profitably again. See id. at 122 (finding that the responsiveness of capital to conditions such as profitability and opportunity costs affects when capital can be invested or reinvested into a harvest). This is not to say that this exploitive pattern is ideal, only that the dangers of irreparable harm are less in some circumstances than others. 
predict, and that are harmful to the entire world.

\section{Distinguished From Other Large-Group Externality Problems}

What I define in this Article as a "true" tragedy of the commons can be distinguished from other large-group externality problems involving jointly-owned or unowned resources. There are two important differences: (1) a tragedy of the commons involves an externality imposed by resource users upon each other by damaging their own ability to exploit the resource, and (2) the exploited resource is rivalrous in consumption.

A tragedy of the commons does not preclude, of course, the imposition of externalities on those outside the group. Fish consumers, ichthyologists, conservationists, and those otherwise intrinsically interested in preserving fish stocks would suffer negative externalities at the hands of the tragic fishermen even as the latter destroy their own livelihood. But as I define it, the existence of an externality imposed by resource users on those outside the group is neither a necessary nor a sufficient condition for a tragedy of the commons. A tragedy of the commons can be selfcontained, with resource users destroying themselves without harming anyone outside of the group. In addition, unless resource users are harming themselves by overexploitation, the imposition of an externality upon those outside the group does not, by my definition, make the situation a tragedy of the commons.

Consider the example of air pollution. Hardin himself thought this to be an example of a tragedy of the commons, only air pollution involves the excessive putting in of something-pollution-rather than the excessive taking out of a scarce resource. ${ }^{63}$ There is a similarity in the calculus facing the individual in that the polluter enjoys the full benefit of polluting by saving money on pollution controls, ${ }^{64}$ just as the herdsman enjoys the full benefit of grazing an additional animal by reaping the profits of another animal. ${ }^{65}$ In both cases the costs of this behavior are shared among many. ${ }^{66}$ However, whereas there is a paternalistic justification for intervention in a tragedy of the commons, intervention in the more general case of air pollution may need to be justified on the grounds of internalizing externalities to others.

${ }^{63}$ Hardin, supra note 1, at 1245.

${ }^{64} I d$.

${ }_{65} I d$. at 1244.

${ }^{66}$ Id. at $1244-45$. 
It is true that air polluters would benefit from pollution regulation in an indirect way as members of the air-breathing public. Is the difference, then, between a tragedy of the commons and other large-group externality problems merely a matter of degree? The answer is no because in a tragedy of the commons, regulation confers very different benefits upon the resource users than upon the larger group. In the overfishing case, regulation that saves fish stocks confers upon the general public a continued and stable supply of fish, ecological integrity by preserving a possibly important part of the aquatic ecosystem, and perhaps the psychic value of knowing that we have not decimated yet another species out of carelessness. Like the rest of the world, fishermen enjoy these benefits. But what is additionally conferred upon the fishermen is a continued ability to fish and practice their livelihood. This is a benefit that is very different from those consumption and conservation benefits that are enjoyed by the diffuse public, and the existence of this additional benefit is what characterizes a tragedy of the commons.

By contrast, regulation that reduces air pollution yields similar benefits to air polluters and air breathers alike. There is no argument that limiting air pollution helps air polluters in any way in their polluting efforts, or preserves their ability to pollute in the future. Thus, while all large-group externality problems will realize benefits from regulation that inure to the large group (typically the general public), in a tragedy of the commons resource users will receive the additional benefit of being saved from their own improvidence as well as the ability to carry on in the future with their resource exploitation.

Intervention may be entirely warranted, perhaps even compelling, for a variety of large-group externality problems such as air and water pollution. ${ }^{67}$ But the nature of the justification for such large-group externality problems is apt to be different than it is for tragedies of the commons. The justification for arresting other large-group externality problems may be varied and complicated, and may involve difficult ethical questions regarding tradeoffs between economic growth and ecological or human health. A costbenefit analysis may or may not be appropriate for making such

${ }^{67}$ A cost benefit analysis of the Clean Air Act, for example, showed compliance costs of over $\$ 500$ billion, but environmental benefits in excess of $\$ 22$ trillion. U.S. ENVTL. PROT. AGENCY, The Benefits AND Costs of THe Clean AIR ACT, 1970 TO 1990, at ES-8 (1997), available at http://www.epa.gov/air/sect812/812exec2.pdf. 
decisions. But the case for arresting tragedies of the commons is apt to include one simple, and compelling additional justification: save the resource users from themselves. A well-designed intervention can yield a Pareto Superior outcome or a near-Pareto Superior outcome. This is also not to say that successful regulation is always possible or feasible; however the case for trying is stronger.

The second distinguishing feature of a tragedy of the commons is that the resource being overexploited is rivalrous in consumption. ${ }^{68}$ Rivalrous consumption is what gives urgency to the race to exploit, and creates compelling incentives to cheat. ${ }^{69}$ This incentive is illustrated by the game theory model of the tragedy above in which A's abstinence, even temporary, resulted in her having an inferior payoff to B in every time period. ${ }^{70}$ This derives simply from the fact that there are a limited number of fish. With a non-rival resource problem such as air pollution, the capacity to pollute is not hindered by the amount of pollution itself. However harmful air pollution has been for public health, polluting has not bumped up against any absolute physical limits that would prevent polluters from continuing to pollute. Polluters thus do not face the same compelling incentives to pollute. ${ }^{71}$ To be sure, there are competitive forces that compel polluters to pollute, but there is no race to spew out the pollution before someone else has the opportunity.

\section{Other Examples of Tragedies of the Commons}

The tragedy of the commons is usually considered a story about property and property rights. For example, one prescription for fixing the tragedy is the establishment of private property rights so that there is no externality. ${ }^{72}$ Like property law itself, the tragedy of the commons has insinuated itself into a variety of problems not

\footnotetext{
68 See LESSIG, supra note 2, at 22 (noting that without rivalry for a resource in the commons, that resource will not be consumed and subsequently made unavailable).

${ }^{69}$ See discussion supra Part II.A (addressing mutual, uninternalized externalities, one of the elements of a "true" tragedy of the commons).

70 See supra Part II.A.

${ }^{71}$ Lessig argues that for nonrivalrous goods, there is no possibility of a "tragedy of the commons," since nonrivalry means that availability for users does not diminish with increased consumption. LESSIG, supra note 2, at 22. Lessig is arguing for leaving in the commons some intellectual property because of the positive network effects of such knowledge. Id. at 26, 85. However, the point of the tragedy of the commons metaphor, as applied to pollution problems, is that there are negative externalities associated with pollution that do not diminish pollution opportunities but should nevertheless be curtailed.

${ }^{72}$ Hardin, supra note 1, at 1245.
} 
involving real property, or any physical res. Similarly, it is worth remembering the lessons that property problems teach us for purposes of solving a variety of public policy problems outside of the property realm.

\section{Traffic Congestion}

Among students who have taken my environmental law courses in both Canada and the U.S., the most consistently identifiable tragedy of the commons problem is that of traffic congestion. Traffic congestion provides an excellent pedagogical device for teaching the tragedy of the commons. Because all drivers face the same decision environment, the problem of traffic illustrates the role of mutuality in explaining the persistence of an externality. Also, the traffic problem showcases the importance of transaction costs in frustrating non-coercive solutions, in that negotiations among commuters are impossible. Finally, traffic congestion illustrates the effects of overutilization of a resource that is rivalrous in consumption: roads. Like other tragedies of the commons, resource users inflict losses upon themselves as a group in terms of the ability to use the resource, by lengthening commute times and degrading the transportation resource.

Externalities are also imposed upon non-users, the air-breathing public, in the form of pollution. But this is a separate and distinct large-group externality that is not itself the tragedy of the commons. The politically safest justification for intervention is to save commuting drivers and protect their commuting experiences. Significantly, the hue and cry for solving traffic problems comes more typically from frustrated drivers than from those who worry about the air pollution externality being imposed upon the general public. ${ }^{73}$

The traditional engineering solution to traffic congestion has been

${ }^{73}$ See, e.g., Chip Jones, Thinking Outside the Boxcar Warner Funding Initiative Sparks New Hopes for Passenger Rail Service, RICH. TIMES DISPATCH, Dec. 27, 2004, at D-12 (noting that a rail expansion plan in Northern Virginia promised to bring relief to angry commuters "tired of getting stuck in car traffic"); Duane D. Stanford, Toll Lanes Urged to Ease Gridlock; Private Contractors' Proposal Would Use Truck-Only Lanes, Express Buses on I-75, I-575, ATLANTA J.-CONST., Nov. 30, 2004, at 1A ("Frustrated commuters would be able to buy their way out of traffic jams or ride trainlike express buses if the newest proposal to attack long commutes on Interstates 75 and 575 through Cobb and Cherokee counties is enacted."); Stephen Ginsberg, Va. To Build Beltway Toll Lanes; Private Funding is Key; Car Pools Would Be Exempt, WASH. POST, Aug. 27, 2004, at A01 ("Officials have embraced the concept as a way to give motorists relief from chronic tie-ups."). 
to expand roadway capacity. ${ }^{74}$ This is often a self-defeating strategy as expanding roadway capacity has the effect of reducing transportation costs so that new demands are created by new users-new residential development, for example-that springs up specifically because of the new roadway capacity. ${ }^{75}$ This is an example of the kind of solution that ignores the second-order effects, those effects that are easily seen once one appreciates the nature of the externality. A fisheries economist would easily understand that even if it were physically possible to respond to overfishing by stocking the fishery with more fish, it would be an exercise in futility. This would only attract more fishermen to come in and participate in the tragedy.

More thoughtful approaches to traffic congestion have thus been oriented towards internalizing the congestion externality, and trying to alter the incentives to participate in the tragedy. This has been attempted by trying to draw people out of the pool of resource users, by imposing a time-of-day-sensitive congestion $\operatorname{tax}^{76}$ and by subsidizing alternative transportation modes such as transit and bicycling. ${ }^{77}$ Further, incentives may be provided to induce people to at least make utilization of the roads more efficient, by encouraging carpooling through the creation of high-occupancy vehicle lanes. ${ }^{78}$ While not exactly like the overfishing problem, traffic congestion creates the same dynamics. ${ }^{79}$

\section{Performance-enhancing Substances in Sports}

Seemingly continuous revelations about the use of performanceenhancing drugs being used by professional athletes have exacted a toll on the image of the affected sports. Last year, baseball star Barry Bonds demurred suspiciously to inquiries regarding his

${ }^{74}$ Robert H. Freilich \& S. Mark White, Transportation Congestion and Growth Management: Comprehensive Approaches to Resolving America's Major Quality of Life Crisis, 24 LOY. L.A. L. REV. 915, 926 (1991).

${ }^{75}$ See id.; Lior Jacob Strahilevitz, How Changes in Property Regimes Influence Social Norms: Commodifying California's Carpool Lanes, 75 IND. L.J. 1231, 1247 n.76 (2000).

${ }^{76}$ Strahilevitz, supra note 75 , at 1243-44.

77 Id. at 1244-45 \& n.65; Oliver A. Pollard, III, Smart Growth: The Promise, Politics, and Potential Pitfalls of Emerging Growth Management Strategies, 19 VA. ENVTL. L.J. 247, 260 (2000).

78 Strahilevitz, supra note 75 , at $1238-39$.

79 The traffic problem is somewhat different from the overfishing problem in that there are no "stock" effects in which excessive current consumption somehow harms the potential for future consumption. But the rivalrous nature of the resource still creates compelling incentives to cheat. Indeed, no serious attempt is ever made to induce people to not drive so as to make others' commutes more expedient. 
knowledge about substances his trainer provided him that are now thought to have been steroids. ${ }^{80}$ Bonds claims to have believed that he was receiving flaxseed oil from his trainer, who remains under federal indictment for his connection with an alleged trafficker of illegal performance-enhancing drugs. ${ }^{81}$ Bonds has hit 703 career home runs, and is within reach of Hank Aaron's Major League record of 755 home runs, a feat that would normally be cause for celebration. 82 But Bonds, never a popular star to begin with, has seen his image further tarnished by this scandal, and it seems likely that his remarkable accomplishments will be overshadowed by his suspected steroid use. ${ }^{83}$

There are athletes that would not trade places with Bonds, knowing that the use of such substances could exact a health toll in the long run. Anabolic steroids have been linked to a variety of health disorders, such as infertility, baldness, distorted genitalia, and a heightened danger of drug dependence. ${ }^{84}$ And yet, because of the exorbitant payoffs of baseball success, there are those that choose to make that tradeoff. ${ }^{85}$ The late baseball star Ken Caminiti, who in a 2002 interview became one of the first baseball players to admit to using steroids, remained unapologetic for using them. Two years before his death by drug overdose, Caminiti told a Sports Illustrated reporter that he felt steroids had become a "widely accepted" and even "necessary" means of maintaining a competitive edge in baseball. ${ }^{86}$ Caminiti estimated that "at least half" of all Major League players use steroids. ${ }^{87}$ This estimate is consistent with the estimate of former outfielder Chad Curtis, who played with

${ }^{80}$ Dave Anderson, Sports of The Times; Bonds's Excuse Has the Scent Of Snake Oil, Not Arthritis Balm, N.Y. TIMEs, Dec. 7, 2004, at D1; Dave Anderson, 2004: Steroids; Bonds and Giambi Testify And Change the Playing Field, N.Y. Times, Dec. 26, 2004, at 87 [hereinafter Anderson, Steroids].

${ }^{81}$ Anderson, Steroids, supra note 80, at 87.

82 Donna Liquori, At a Shrine to Baseball, Steroid Inquiry Inspires Shame, N.Y. TIMES, Dec. 5, 2004, at 146.

${ }^{83}$ Art Thiel, Baseball Immortality Bruised by Injuries, SeATtLe Post-InTELLIGENCER, Feb. 10, 2005, at D1 (“The Giants' star has 703 home runs, but the steroids scandal has baseball in a magnum twist about how to salute the pending surrender of its most hallowed individual record by a guy who looks more and more like a sports crook.").

${ }^{84}$ Mayo Clinic, Performance-enhancing drugs: Dangerous, damaging and potentially deadly, http://www.mayoclinic.com (last visited Feb. 17, 2005).

${ }^{85}$ In effectively admitting steroid use, Bonds joins other baseball sluggers such as the late Ken Caminiti, Gary Sheffield, Jason Giambi, and Jose Canseco. Dave Anderson, Sports of The Times; Is Anybody Listening to Caminiti's Steroids Alarm?, N.Y. Times, Oct. 13, 2004, at D4; Anderson, Steroids, supra note 80; Filip Bondy, Book of Lies? No Way, Jose! Canseco's charges have juice, DAILY NEWs (N.Y.), Feb. 14, 2005, at 52.

86 Tom Verducci, Totally Juiced, SPORTS ILLUSTRATED, June 3, 2002, at 34, 36.

${ }^{87} I d$. 
six teams in ten major league seasons. ${ }^{88}$ Major League Baseball physicians estimated that ten to fifteen percent of all minor league players they examined tested positive for steroids. ${ }^{89}$

Baseball success is an extremely lucrative resource that is perfectly rivalrous in consumption. Winning necessarily precludes winning by others. Achieving and maintaining a competitive edge, even a small one, can be the difference between success and failure. The incentive to cheat by using steroids and other performanceenhancing substances is intense. In the same Sports Illustrated interview, Caminiti offered this perspective on the use of steroids:

If a young player were to ask me what to do ... I'm not going to tell him it's bad. Look at all the money in the game: You have a chance to set your family up, to get your daughter into a better school. . . . So I can't say, 'Don't do it,' not when the guy next to you is as big as a house and he's going to take your job and make the money. ${ }^{90}$

While Caminiti evinces no regrets for using steroids, he clearly recognizes that steroids are a necessary evil due to the competitive pressures of baseball. Putting aside the loss to those players that can successfully cheat and could not succeed at baseball without cheating, it seems clear that the vast majority of players would be better off with an effective and enforceable ban on the use of performance-enhancing drugs. Ballplayers would then face a baseball career not competing with cheaters that use performanceenhancing drugs, not being pressured to cheat, and if already cheating, not being pressured to cheat more, and cheat in more expensive and even more unhealthful ways. It is thus the playersthe resource users - that truly do need to be saved from themselves. Appeals by civil libertarians would ring somewhat hollow in this context.

The use of performance-enhancing drugs is not limited to American baseball players. The mysterious deaths of eight young, apparently healthy, professional cyclists in a seventeen-month period spanning 2003 and 2004 would be shocking if there had not already been strong suspicions that the sport is still plagued by the misuse of dangerous performance-enhancing drugs and by dangerous blood-doping practices. ${ }^{91}$ Even 1998 Tour de France

\footnotetext{
${ }^{88}$ Id. at $37,48$.

${ }^{89} I d$. at 42.

90 Id. at 36.

${ }^{91}$ Ron Kroichick, Sports and Drugs Cycle of Tragedy; Baseball has BALCO, But Europe Is
} 
champion Marco Pantani, who died mysteriously in 2004 from a drug overdose, had been ejected from a race in 1999 for blood doping and had continually battled allegations of blood doping and drug use since then. ${ }^{92}$ It is incredible that cyclists persist in taking such high risks to succeed, particularly one of Pantani's stature. But given the highly rivalrous nature of winning cycling races, the incentive to cheat is apparently irresistible. Clearly, cyclists would benefit from an enforceable and effective ban since they would no longer find it necessary to cheat and risk their lives to succeed. The apparent impossibility of enforcing such a ban, however, does not portend well for the sport.

\section{Informational Privacy}

Professor Dennis Hirsch has likened the loss of informational privacy to a tragedy of the commons. ${ }^{93}$ The overuse of personal information that leads to unwelcome solicitations and possibly nefarious uses of that information has increased dramatically, and has caused some to withdraw from electronic commerce. Under the Gramm-Leach-Bliley Act of 1999, firms may share personal information collected from customers with other firms under a fairly broad "joint marketing" exception. ${ }^{94}$ The exception allows the sharing of information with unrelated firms if done "pursuant to joint agreements between two or more financial institutions." 95 Given the ease of sharing highly useful information about buying preferences in an electronic format that is easy to process, the shortterm benefits to firms of sharing information are huge. Even if just a small fraction of the information turns out to be useful in generating additional sales, the benefit will easily outweigh the low costs of this release of information. Professor Peter Swire, who has praised most of the Gramm-Leach-Bliley Act, is critical of this broad exception, which is most likely to be inconsistent with consumer expectations of what can be done with personal information

Plagued With Its Own Sports Drug Scandal: EPO and Bicycling, S.F. Chronicle, May 9, 2004, at C1.

${ }_{92}$ Id.; Obituaries, Marco Pantani, 34; Italian Cyclist Plagued by Doping Allegations, L.A. Times, Feb. 15, 2004, at B19.

${ }_{93}$ See generally Dennis D. Hirsch, Is Privacy Regulation the Environmental Law of the Information Age?, in PRIVACY AND TEChNOLOGIES OF IDENTITY: A CROsS-DiscIPLINARY CONVERSATION (Katherine Strandburg \& Daniela Stan Raicu eds., forthcoming 2006).

94 15 U.S.C. $\$ 6802(\mathrm{~b})(2)(2000)$.

${ }_{95} I d$. 
provided in the course of a commercial transaction. ${ }^{96}$ Although evidence of consumer reluctance to engage in electronic commerce appears at this point to be inconclusive, ${ }^{97}$ there clearly remains the danger that this overuse of information will lead to consumer trepidation that could chill information-generating commercial transactions. ${ }^{98}$

The tragedy of the commons can be seen more clearly in the invasion of our e-mail inboxes with spam. Spam is trivially cheap to send, making it an economical practice if only as few as one in 100,000 spam recipients becomes a customer. ${ }^{99}$ The sending of spam has taken off, rising from eight percent of all e-mail messages in 2001 to approximately fifty percent of all e-mail, totaling two trillion messages sent in 2003. ${ }^{100}$ While some services have developed spam filters, spam remains a fairly obnoxious disamenity associated with using what has become an indispensable electronic utility. A recent study found that e-mail users spend an average of three minutes per day deleting spam, which multiplies out to 22.9 million hours per week, and a staggering $\$ 21.58$ billion per year based on an average wage. ${ }^{101}$ The tragedy of this commons, however, is not even the waste of our time but the loss of opportunity to use e-mail for marketing purposes, as legitimate marketers struggle to distinguish themselves from those selling cheap drugs and penis enlargers through spam. ${ }^{102}$

\section{THE OvERFISHING PROBLEM}

\section{Despite the many applications of Hardin's tragedy of the}

${ }^{96}$ Peter P. Swire, The Surprising Virtues of the New Financial Privacy Law, 86 MinN. L. REV. 1263, 1296 (2002).

${ }_{97}$ See Robert E. Litan, Law and Policy in the Age of the Internet, 50 DUKE L.J. 1045, 1058 n.46 (2001) (referencing a Harris survey which found that 92\% of respondents were "concerned" and $67 \%$ were "very concerned" that their personal information was being misused).

${ }_{98}$ Concern over recent thefts of personal information at data clearinghouses such as Choice Point and LexisNexis have led to activity in the U.S. Senate Banking, Housing, and Urban Affairs Committee. Tom Zeller, Jr., Consumer Data Stolen From LexisNexis, INT'L HERALD TRIB., Mar. 11, 2005, at 13 . The activity by the congressional committee is a sign that consumer anxiety about control of personal information remains high.

${ }_{99}$ AOL, Microsoft Seek Federal Help on Spam, MilwaUkeE J.-SEnTinel, Feb. 23, 2003, at D4.

${ }^{100}$ S. REP. NO. 108-102, at 2-3 (2003), as reprinted in 2003 U.S.C.C.A.N. 2348, 2349.

101 Thomas Claburn, Spam Costs Plenty, INFO. WeEK, Feb. 7, 2005, at 15.

102 See Chris Gaither, Clearing Way for Legitimate E-Mail? Marketers Hope Antispam Law Restores Industry's Reputation, BosTon GLOBE, Dec. 1, 2003, at C1 (stating that "the sharp rise in the amount of spam... has made computer users quick to delete anything they perceive as unwanted—or to report it to their Internet service providers as spam"). 
commons, open access fisheries have somehow borne out Hardin's predictions the most faithfully. Virtually every overfished fishery in the world has followed the same pattern of overexploitation over time. First, a previously unexploited open access fishery is "discovered," or somehow becomes the target of fishing, and the initial abundance of fish creates easy fishing conditions that provide large profits for the first entrants into the fishery. Second, this prospect of large profits attracts new boats that crowd the fishery. Lastly, the increase in fishermen results in a depleted fish stock, making fishing more and more difficult, until the fish stock completely collapses, in the meantime impoverishing the fishermen. Examples abound, but a particularly striking example of this dynamic is provided by the late nineteenth-century and early twentieth-century Pacific halibut fishery, exploited primarily by U.S. and Canadian boats. ${ }^{103}$ Because of the availability of data going back to the late nineteenth century, the Pacific halibut fishery provides an excellent opportunity to examine the economic and ecological dynamics of fishing, the interaction of fishermen with fish over time, and the sometimes symbiotic relationship between the two.

The Pacific halibut fishery was essentially unregulated until $1924,{ }^{104}$ when the United States and Canada created by treaty the International Fisheries Commission, a body charged with studying the halibut fishery and making recommendations on halibut fishery management. ${ }^{105}$ The 1924 treaty also created a fishing season, limiting halibut fishing to nine months of the year. ${ }^{106}$ The lack of regulatory limitations on halibut fishing during the nine-month season negated any beneficial effect produced by the three month closing. ${ }^{107}$ Binding limitations took effect in 1931, however, after the United States and Canada signed a new treaty which

${ }^{103}$ A narrative description of the development of the Pacific halibut fishery highly similar to that provided above can be found in Int'l Fisheries Comm'n [IFC], Regulation and Investigation of the Pacific Halibut Fishery in 1947, IFC Rep. No. 13, at 7-8, 16 (1948), available at http://www.iphc.washington.edu/halcom/pubs/scirep/Report0013.pdf.

104 By "unregulated," I mean to say that there were no quantitative limitations on fishing. American and Canadian halibut markets remained relatively open to imports, and neither government was particularly inclined to exclude fishing boats from their neighboring country. Thus, although there were still regulatory requirements, they did not impose any limits on fishing. See generally id. at 7.

${ }^{105}$ Id. at $7-8$.

106 Id. at 8 .

107 William F. Thompson \& F. Heward Bell, IFC, Biological Statistics of the Pacific Halibut Fishery, IFC Rep. No. 8, at 11 (1934), available at http://www.iphc.washington.edu/ halcom/pubs/scirep/Report0008.pdf. 
implemented aggregate catch limits for several intensively-fished areas. ${ }^{108}$ The new convention produced an immediate reduction in the amount of fishing effort and a concomitant increase in fishing efficiency. 109

The early twentieth-century history of the Pacific halibut fishery illustrates: (i) the incentive for individual fishermen to overfish, resulting in a collective overfishing; (ii) a general increase in effort in fishing; and (iii) a markedly consistent decrease in fishing efficiency, measured by quantity of catch per quantity of fishing effort. Table 4 shows recorded pacific halibut landings on the Pacific Coast of Southeastern Alaska, Canada, and Washington State for the years 1910 to 1933.110 The second column shows the total pounds of halibut landed for the year. The third column shows the total number of utilized "skates." 111 The fourth column provides a measure of fishing efficiency by listing a "catch-per-unit-effort" known as the catch per skate.

${ }^{108} I d$. at 11,13

109 Id. at 13-14. Thompson and Bell concluded that the "rise in catch per unit . . is due in 1932 and 1933 to regulation, which has deliberately held the total catch at a level after an initial decline in the amount of fishing, and despite the resultant rise in catch per unit." Id. at 23 .

${ }^{110}$ Pacific halibut were divided into two distinct stocks, one that stayed generally south of Cape Spencer, and one that generally stayed west of Cape Spencer. Id. at 19. Statistics concerning halibut landings for the individual stocks are very similar to each other in the years 1923 through 1933. Id. at 12 .

111 A "skate" is a ground fishing line that has a fairly standardized number of hooks per unit of length. Id. at 21 . 
TABLE $4^{112}$

\begin{tabular}{|c|c|c|c|}
\hline Year & Pounds landed & $\begin{array}{c}\text { Number of } \\
\text { Skates }\end{array}$ & $\begin{array}{c}\text { Catch per } \\
\text { Skate (lbs) }\end{array}$ \\
\hline 1910 & $51,849,240$ & 191,325 & 271.0 \\
\hline 1911 & $56,931,796$ & 240,219 & 237.0 \\
\hline 1912 & $60,379,550$ & 343,066 & 176.0 \\
\hline 1913 & $56,235,578$ & 436,273 & 128.9 \\
\hline 1914 & $45,276,669$ & 364,840 & 124.1 \\
\hline 1915 & $45,025,016$ & 381,568 & 118.0 \\
\hline 1916 & $30,218,908$ & 263,690 & 114.6 \\
\hline 1917 & $31,602,797$ & 386,342 & 81.8 \\
\hline 1918 & $27,070,659$ & 309,379 & 87.5 \\
\hline 1919 & $27,402,631$ & 332,960 & 82.3 \\
\hline 1920 & $33,158,192$ & 394,271 & 84.1 \\
\hline 1921 & $37,476,466$ & 487,340 & 76.9 \\
\hline 1922 & $31,294,067$ & 499,915 & 62.6 \\
\hline 1923 & $28,844,269$ & 504,270 & 57.2 \\
\hline 1924 & $27,004,148$ & 483,945 & 55.8 \\
\hline 1925 & $23,941,311$ & 462,187 & 51.8 \\
\hline 1926 & $25,790,876$ & 494,078 & 52.2 \\
\hline 1927 & $24,630,270$ & 498,588 & 49.4 \\
\hline 1928 & $27,209,093$ & 569,228 & 47.8 \\
\hline 1929 & $26,253,998$ & 653,085 & 40.2 \\
\hline 1930 & $22,598,895$ & 643,843 & 35.1 \\
\hline 1931 & $22,473,326$ & 548,130 & 41.0 \\
\hline 1932 & $22,881,718$ & 456,721 & 50.1 \\
\hline 1933 & $23,599,734$ & 452,970 & 52.1 \\
\hline
\end{tabular}

Several interesting trends should be noted in Table 4. First, there was a general trend of increases in the number of skates each year, a measure of the amount of fishing effort expended each year. This consistent twenty-one year trend must be considered some evidence of the inexorability of the tragedy. Second, with the exception of just three years before 1930, there was usually a decrease in fishing

${ }^{112}$ Id. at 12 . 
efficiency each year. The dramatic decline in efficiency from 271 to 35 over just twenty-one years is evidence of the severity of the mutual externality halibut fishermen imposed upon each other, as well as evidence of the decline of the halibut stock. Third, there was a general downward trend in the total amount of halibut landed, which represents additional evidence that the health of the halibut stock continuously declined through this period.

In short, the data in Table 4 does a remarkable job telling the story of the tragedy of the commons. An abundant halibut fishery, first exploited in 1888, is a profitable one in 1910. The profitability causes more boats to enter, as reflected by the increase in skates. Over the next twenty-one years, boats entered and exited the halibut fishery, but there was no question that the fishing became more difficult, as reflected by the steady decrease in fishing efficiency. The decrease in fishing efficiency is also a sign of a declining halibut stock. Fortunately, this story has, at least by the 1930 s, a relatively happy ending-intervention in the form of a treaty takes place that limits the amount of halibut fishing. Profitability, as reflected by fishing efficiency, starts upward again.

The lessons of the early twentieth-century halibut fishery are two-fold. Clearly, regulation was needed to save the resource and preserve it for the entire world. But regulation was also needed to save the fishermen from themselves. As fishing efficiency spiraled steadily downward, fishermen were caught in the trap of having to fish just to salvage what they could from a depleted stock. Failure to fish, giving up on the race to fish, meant having their only valuable capital asset-their boat-sit idle. With many fishermen still paying off loans on their boats, idleness was not an option.

The poverty trap that has engulfed many fishing communities is in fact what has motivated economists to study the open access fishing problem. As early as 1955, H. Scott Gordon derived the mechanism by which fishing communities invariably fished themselves into a bust cycle in which they discovered an abundant fish species, rushed in with too many boats, and wound up overfishing the stock to the brink of a collapse, with the fish stocks utterly unable to provide fishing communities with sufficient income to fend off poverty. ${ }^{113}$

${ }^{113}$ Gordon's theoretical findings that fishing will continue to a point beyond the optimal and beneficial level find support from studies of the halibut case. See William F. Thompson \& Norman L. Freeman, IFC, History of the Pacific Halibut Fishery, IFC Rep. No. 5, at 10 (1930), available at http://www.iphc.washington.edu/halcom/pubs/scirep/Report0005.pdf ("The great effect of inconspicuous mechanical changes and of cheaper power explains on the one hand 
Regulation was thus needed not only to save the Pacific halibut, but to save the halibut fishing industry. ${ }^{114}$ This latter aspect is the one conveniently overlooked by categorical opponents of regulation, those unqualified libertarians for whom the answer to everything is deregulation or privatization. There is often the implicit assumption that any form of regulation is a subtraction from an individual right, and that it invariably diminishes the wealth or utility of the regulated individual. ${ }^{115}$ This assumption overlooks the gains to be had from cooperation, and gains that can be created by institutions, governmental or otherwise, that facilitate and even mandate cooperation.

\section{The CAMPaign Finance PROBlem}

\section{A. Overfishing for Votes}

Ubiquitous campaign advertisements in all kinds of media seem to have accomplished two things: numbing the voting electorate to campaign advertisements, and cultivating a concern over the role of money in political campaigns, particularly federal ones. ${ }^{116}$ The pervasive nature of campaign advertising has dulled voters' senses to the messages behind the advertising. One study reported that registered voters saw an average of almost eight campaign ads on TV per day during the week leading up to the 2002 congressional

the present existence of the fishery despite a greatly lowered abundance, and on the other indicates... that the decline will be continued far beyond the limit which seems at present profitable." (emphasis added)).

${ }_{114}$ For one of many accounts of how the failure to regulate resulted in the wreckage of the Atlantic cod fishery, see generally Michael HaRRIs, LAMENT FoR AN OCEAN: THE Collapse of the Atlantic Cod Fishery, A TRUe CRIMe Story 66-67 (1998) (discussing how improvements in technology coupled with the lack of regulation and poorly enforced regulation lead to the demise of the Atlantic cod fishery).

115 The Reagan Administration disapproved a plan which would have more strictly regulated the beleaguered halibut fishery because it "ran counter to the free market." John Balzar, A Catch as Catch Can Fish Plan, L.A. Times, June 28, 1992, at A1. As aides explained, "As an Administration, we're just opposed to limiting fishing to only those who have formerly fished.... We are concerned that it would interfere with basic economic liberties." Id.

116 See, e.g., Carl Hulse \& Anne E. Kornblut, McCain Allies Seek Reform and the Money to Get It, N.Y. TimES, Mar. 8, 2005, at A18. Additionally, states have not been spared from the cycle of campaign spending for state-wide elections. The number of political action committees [PACs] in Virginia to address state elections has nearly doubled in the last four years, reflecting the ballooning costs of seeking statewide elective office. R.H. Melton, Campaign Costs Soar, Prompting Va. Power PACs; Groups Serve Specific Interests, Helping Donors Direct Dollars, WASH. PosT, June 2, 2003, at B01. 
campaign. ${ }^{117}$ Ballooning campaign expenditures and the increasing amount of time and effort politicians spend fundraising have fueled a suspicion that money has gained more than just a toehold over political institutions and processes. ${ }^{118}$ Former Congressman Lee Hamilton, as director of the Center on Congress at Indiana University, has lamented this voter cynicism:

The rising flood of money that flows into campaigns also undermines general public trust in the political system. Many Americans feel it is money, not ideas and not principles, that reigns supreme in our political system. I often heard people say that the political process was run by the moneyed interests, so they saw little reason to vote. ${ }^{119}$

This widespread suspicion only exacerbates the anesthetizing properties of campaign speech. A perception that a political candidate has been bought and paid for only dulls the viewer to the substantive aspects (if any) of campaign speech. A report by the Pew Center for the People and the Press found that while the 2000 presidential campaign was generally better in terms of information available, candidates' commercials were considered less effective than they were in $1992 .{ }^{120}$ One might not be surprised that pundits are loudly crying foul in response to the increased use of private funds in political campaigns, ${ }^{121}$ but not even critics of campaign finance reform proposals believe that the system we have for running political campaigns is particularly good. ${ }^{122}$

Debates about the efficacy of and problems with campaign speech,

117 David B. Magleby \& J. Quin Monson, CtR. For the Study of Elections AND Democracy, Brigham Young Univ., CAMPAign 2002: “The Perfect Storm” 7, 18 (2002).

118 Lee Hamilton, The Ctr. ON Cong. AT Ind. Univ., The Money Chase, http://congress.indiana.edu/radio_commentaries/the_money_chase.php (last visited on Oct. 3, 2005).

${ }^{119} I d$.

120 Pew Research Ctr. for the People and the Press, Campaign 2000 Highly Rated 2 (2000), available at http://people-press.org/reports/print.php3?ReportID=23.

121 See, e.g., David S. Broder, Level the Presidential Playing Field, WASH. PosT, Oct. 19, 2003, at B07; E.J. Dionne, Jr., How to Fix Financing, WASH. Post, Nov. 28, 2003, at A41; Thomas B. Edsall \& Dan Balz, Kerry to Forgo Public Campaign Financing; Democrat Says He Will Use Own Money, WAsh. Post, Nov. 16, 2003, at A12; Editorial, Your Turn; Fix the Finance Rules for Presidential Races; The Public-Financing Program for Presidential Candidates, Designed to Even the Playing Field, is Broken, SAN ANTONIO ExPRESS-NEWS, Nov. 12, 2003, at 6B.

122 Bradley Smith, Unfree Speech: The Folly of Campaign Finance Reform, at $x$ (2001) ("Few people like our current campaign finance laws. I certainly don't, and in that respect I am a full-throated 'reformer."); Kathleen M. Sullivan, Against Campaign Finance Reform, 1998 UTAH L. REV. 311, 326-29 (1998) (suggesting possible solutions to campaign finance problems). 
however, are rarely followed by satisfying discussions of solutions. The greatest obstacle to solving the campaign spending problem is that almost any conceivable solution would somehow impinge upon Constitutionally-protected speech. Furthermore, inherent in the debate is the notion that Constitutionally-protected speech is good, and more speech is better. Even campaign finance reform advocates seem willing to concede to the notion put forth in the dissent by Justice Holmes in Abrams $v$. United States, ${ }^{123}$ in which Holmes argued for a "free trade in ideas" and "that the best test of truth is the power of the thought to get itself accepted in the competition of the market." 124 This led to the popularization of the phrase "marketplace of ideas," coined by Justice Brennan ${ }^{125}$ to describe the notion that the best way to ascertain the truth is to have "uninhibited, robust, and wide-open" discussion ${ }^{126}$ serve as an open competition of ideas. The freer the discussion, the more robust the competition and the more certain the truth, goes the reasoning.

The battle over campaign finance reform has been waged with this truism in mind. The campaign finance problem is seen as a clash of the principles of equality and freedom of speech, with free campaign spending being equated with free speech. ${ }^{127}$ Some reform advocates have argued that equality principles have become jeopardized, and that regulation is warranted in order to correct the heavy bias towards those interest groups that tend to be wellfunded. ${ }^{128}$ Inherent in their position is a Rawlsian notion that uncontrolled campaign spending disadvantages the less wealthy

23250 U.S. 616 (1919).

124 Id. at 630 (Holmes, J., dissenting).

${ }^{125}$ Lamont v. Postmaster Gen., 381 U.S. 301, 308 (1965) (Brennan, J., concurring).

126 N.Y. Times Co. v. Sullivan, 376 U.S. 254, 270 (1964).

127 Martin H. Redish, Money Talks: Speech, Economic Power, and the Values of DEMOCRACY 136-39 (2001); SMITH, supra note 122, at 10-11 (2001); see, e.g., Spencer A. Overton, Mistaken Identity: Unveiling the Property Characteristics of Political Money, 53 VAND. L. REV. 1235, 1253-56 (2000).

${ }^{128}$ See, e.g., Burt Neuborne, Toward A Democracy-Centered Reading of the First Amendment, 93 Nw. U. L. REv. 1055, 1055-57 (1999) (refuting the Court's assertion in Buckley v. Valeo, 424 U.S. 1 (1976), that corruption is the only justification for campaign finance reform and arguing that political equality should be acknowledged as a "compelling' justification" for limits on spending); Richard Briffault, The Future of Reform: Campaign Finance After the Bipartisan Campaign Reform Act of 2002, 34 ARIZ. ST. L.J. 1179, 1213 (2002) (commenting that campaign finance regulations do nothing to combat large individual and PAC contributions to incumbents, leading to their overwhelming economic advantage); Yoav Dotan, Campaign Finance Reform and the Social Inequality Paradox, 37 U. MICH. J.L. REFORM 955, 998-99 (2004) (arguing that judicial intervention is justified in a system of market inequalities where the elite may use their "economic leverage" to distort the democratic process). 
and violates equality principles. ${ }^{129}$ Detractors of campaign finance reform, on the other hand, argue that given the necessarily clumsy and ultimately flawed ways of regulating campaign finance, it is better to stick with the principle that is easier to defend-freedom of speech, and relative freedom to contribute to campaigns. ${ }^{130}$ I do not weigh in on this equality versus freedom debate, except to say it is the wrong debate.

Some reform advocates take their cue from Judge Skelly Wright ${ }^{131}$ and from Justice Stevens' concurring opinion in Nixon v. Shrink Missouri Government PAC, ${ }^{132}$ and take issue with the notion that campaign money is purely "speech." The argument of this camp of reformers has been that campaign contributions implicate property interests, not speech interests. ${ }^{133}$ This view would presumably bifurcate the spending of money and the use of that money to purchase speech, as acts of separate legal import. For purposes of this Article, I put aside this objection to consider the impacts of the spending and the speech taken together. I do not weigh in on this "property vs. speech" debate. Although this Article will briefly discuss the Bipartisan Campaign Reform Act of 2002, I do not weigh in on the important question of what can and should be done to regulate non-candidate or third-party expenditures and contributions. This Article only speaks to speech, and its effects on speech itself.

Neither reform advocates nor detractors have examined the underlying premise of the free speech argument: that more speech

129 See John RAWLS, POLITICAL LIBERALISM 360 (1993) (observing that wealthier candidates under the present system are more able to unfairly manipulate the electoral process to their advantage); see also Colin Feasby, Libman v. Quebec (A.G.) and the Administration of the Process of Democracy under the Charter: The Emerging Egalitarian Model, 44 MCGILL L.J. 5, 9-11 (1999) (stating that the largest hurdle to achieving equality in political participation is personal affluence).

${ }_{130}$ See, e.g., SMITH, supra note 122 , at 194, 198-200; Sullivan, supra note 122, at 311-13; Eugene Volokh, Why Buckley v. Valeo Is Basically Right, 34 ARIZ. ST. L.J. 1095, 1095-97 (2002).

131 J. Skelly Wright, Politics and the Constitution: Is Money Speech?, 85 YALE L.J. 1001, 1005-06 (1976).

${ }^{132} 528$ U.S. 377, 398 (2000) (Stevens, J., concurring) ("Money is property; it is not speech.”).

${ }_{133}$ REDISH, supra note 127, at 122-25; see, e.g., Edward B. Foley, Equal-Dollars-Per-Voter: A Constitutional Principle of Campaign Finance, 94 Colum. L. REV. 1204, 1222 (1994); Jamin Raskin \& John Bonifaz, The Constitutional Imperative and Practical Superiority of Democratically Financed Elections, 94 ColuM. L. REV. 1160, 1164-66 (1994); Spencer Overton, The Donor Class: Campaign Finance, Democracy, and Participation, 153 U. PA. L. REV. 73, 84-85 (2004) (illuminating the idea that excessive wealth used to "gain political advantage or access" poses a far greater threat to democratic political participation than speech). 
is always better. "Better" in what sense? From the speaker's viewpoint, more speech is always better at the margins, even if the marginal usefulness of speech declines, as it does for all commodities. No campaign ever makes a conscious decision to simply remove their candidate from the airwaves, newspapers, and the internet, or to unilaterally disarm. But from a societal viewpoint, it is becoming clear that at certain levels of campaign speech, it becomes so ubiquitous and so commoditized that it loses its effectiveness. ${ }^{134}$

And yet, candidates for political and even judicial office face everincreasing demands to engage in more and more campaign speech. This, in turn, has led to ever-increasing pressure to raise money, surely one of the most unpleasant tasks facing campaigners. The late Hubert Humphrey called it "a disgusting, degrading, demeaning experience." ${ }^{355}$ But raising large sums of money has become essential to seeking public office, and almost from the very moment that an election victory is secured, candidates must begin the cycle anew, often raising money the morning after an election victory, giving rise to the coinage of the phrase "permanent campaign." 136

In addition to the disamenity value from the candidates' point of view, the compulsion to raise money poses a more serious public policy problem in terms of competing for the incumbent politician's time, a point raised by Professor Vincent Blasi over a decade ago. ${ }^{137}$ Candidates routinely miss important activities, such as floor votes on important legislation, so they can raise more money. ${ }^{138} \mathrm{~A}$ recent

${ }^{134}$ It has become widely noted that trends seem to indicate a growing disillusionment on the part of the voting electorate with the political campaign process generally. Richard L. Hasen, Clipping Coupons For Democracy: An Egalitarian/Public Choice Defense of Campaign Finance Vouchers, 84 CAL. L. REV. 1, 3-4 (1996).

135 HAMILTON, supra note 118.

136 See, e.g., Norman J. Ornstein \& Thomas E. Mann, Preface to The Permanent CAMPAIGN AND ITS FUTURE, at vii (Norman J. Ornstein \& Thomas E. Mann eds., 2000); James A. Thurber, Is the Permanent Campaign Alive and Well After 9/11?, available at http://spa.american.edu/ccps/getpdf.php?table=publications\&ID=47 (last visited Jan. 7, 2006).

${ }^{137}$ Vincent Blasi, Free Speech and the Widening Gyre of Fund-Raising: Why Campaign Spending Limits May Not Violate the First Amendment After All, 94 CoLUM. L. REV. 1281, 1282 (1994) ("A major goal of campaign finance reform is coming to be-and surely ought to be-to protect the time of elected representatives and candidates for office.").

${ }^{138}$ During the 2004 presidential campaign cycle, Democratic presidential hopeful Dick Gephardt, for example, missed $85 \%$ of the House floor votes for the first part of 2003, and eventual nominee John Kerry missed 37\% of all recorded votes in the Senate. Juliet Eilperin, Gephardt, Kerry Miss the Most Hill Votes; Two Draw Focus of Republicans Tallying Absences of White House Hopefuls, WASH. PosT, June 1, 2003, at A04. Former Congressman Lee Hamilton, as Director of the Center on Congress at Indiana University, has lamented that "[t]he money chase distorts the political process, crowding out other activities like writing 
survey of 2200 federal, state, and local candidates reported that more than half of those running for statewide office and approximately 43 percent of those running for the House spent at least one-quarter of their time raising money, ${ }^{139}$ while over twenty three percent spent more than half of their time raising money. ${ }^{140}$

Failure to keep pace with an opponent in fundraising allows the opponent to use airwaves to define the campaign, monopolize public attention, and worst of all, launch attacks that go unanswered. Therein lies the paradox: candidates must raise more and more money to engage in more and more campaign speech, but are finding their speech increasingly ineffective in reaching the hearts and minds of voters. It is an arms race of campaign fundraising and spending.

There are a number of similarities between the overfishing problem and the campaign finance problem that illustrate the dynamics of a tragedy of the commons. Both involve a rival resource. In the case of overfishing, the resource is obviously the fish stock, while in the campaign finance problem the resource is the ability of political candidates to reach the hearts and minds of voters. Both involve the degradation of this resource. In fishing, the fish stock deteriorates, while in the campaign finance context voter interest in campaign messages is lost.

Both problems involve an overexploitation of the resource. Just as fishermen take too many fish, political candidates go to the airwaves too often to try and get a message across to voters. Because more speech is always better from the viewpoint of an individual candidate, the incentive is for the candidate to speak until she has no more money left in her campaign coffers. In essence, candidates are wasting the resource by using it too intensively and too often.

In both situations, individual short-term interests conflict with collective long-term interests. In both situations, the rational course of action from the individual viewpoint is to continue to exploit and ruin the resource. This is due in part to the fact that if any one individual refrains, she cannot count on other individuals to

\footnotetext{
laws, thinking about public policy, or meeting with ordinary voters." HAMILTON, supra note 118.

39 Peter L. Francia, Begging for Bucks-Campaign Fundraising, Apr. 2001, http://www.findarticles.com.

${ }_{140}$ Paul S. Herrnson \& Ronald A. Faucheux, Candidates Devote Substantial Time and Effort to Fundraising, July 7, 2000, http://www.bsos.umd.edu/gvpt/herrnson/reporttime.html; see also Blasi, supra note 137, at 1281-82 (citing fund-raising statistics).
} 
also refrain. The result would be that while the resource is ruined, the refraining individual is the only one that does not enjoy the temporary benefit of the ruination of the resource. Campaigning politicians face this dilemma. There is no incentive to ever refrain from campaigning, or to stop raising money to do it. While campaigning politicians spend less effectively the more they spend, high-minded abstention would still be tantamount to capitulation. But in the long run, all candidates have contributed to the campaign speech malaise of the voting public.

In the section that follows, I make some observations about the campaign speech effort that are similar to those made about fishing effort. Data on campaign spending and voter turnout in U.S. federal elections is presented below to illustrate that campaign spending and spending effectiveness has followed a pattern similar to that of halibut fishing and fishing effort.

\section{B. U.S. Federal Election Data}

As a proxy for campaign speech effort, I use total dollars spent in a federal campaign cycle on U.S. House of Representatives and U.S. Senate campaigns. ${ }^{141}$ There is certainly some inexactness of this measure, as there is with using skates to measure fishing effort. Some campaigns involve close races that draw more money than would otherwise be the case. Some campaigns, such as those conducted by independently wealthy candidates such as 1996 Senate candidate Michael Huffington and Senators Jon Corzine and Herb Kohl, draw upon huge private reserves of money. ${ }^{142}$ However, money remains a better proxy than any other conceivable measure of campaigning effort. Data on person-hours spent on the campaign trail, or on fundraising efforts, even if it existed, would be unreliable.

Data on U.S. federal elections from 1976 to 2002 is used for analysis. This period is bounded by two major changes in the law on campaign finance: Buckley $v$. Valeo was decided in 1976, upholding most of the provisions of the 1974 Federal Election Campaign Act (FECA). ${ }^{143}$ In 2002, the Bipartisan Campaign

\footnotetext{
${ }^{141}$ I also analyzed data on campaign receipts, and the empirical findings did not change.

${ }^{142}$ See Paul A. Clark, Self-Financing of Senate Candidates, 1950-2000: Have Campaign Finance Laws Affected the Behavior of Wealthy Candidates? (unpublished comment), available at http://www.law.uchicago.edu/Lawecon/student-papers/Clark.pdf (last visited Jan. $7,2006)$

${ }^{143} 424$ U.S. $1,143-44$ (1976).
} 
Reform Act (BCRA), ${ }^{144}$ popularly known as the McCain-Feingold Act (after the Senate sponsors) or the Shays-Meehan Act (after the House sponsors), was passed and took effect on November 6, 2002, the day after Election Day. ${ }^{145}$ The BCRA was upheld in large part by the U.S. Supreme Court in McConnell v. FEC. ${ }^{146}$ The BCRA had many effects, but for our purposes the most important were to raise individual contribution limits to candidates for federal office from $\$ 1,000$ to $\$ 2,000,{ }^{147}$ and to limit the use of soft money as a source of funding in campaigns. ${ }^{148}$ It would be inappropriate to compare expenditure data from before and after the BCRA because the difference between direct contributions of $\$ 1,000$ and $\$ 2,000$, as well as differences in soft money contributions, could skew the fundraising data. While the Federal Election Commission obviously continued to make significant rulings during this period from 1978 to 2002, I assume that there were no changes in the legal environment with respect to campaign fundraising and spending that would bias results.

Presidential election years are different from midterm federal election years in both spending and voter turnout. Campaign spending is greater in high-profile competitive election years, such as presidential election years, and these years also experience increased voter turnout. ${ }^{149}$ The result is that campaign spending efficiency-measured in terms of votes per dollar spent-is invariably greater in presidential years. For illustrative purposes, I divide the data into two sets, shown in Tables 5 and 6.

144 Bipartisan Campaign Reform Act of 2002 (BCRA), Pub. L. No. 107-155, 116 Stat. 81 (codified primarily in scattered sections of 2 and 47 U.S.C.A.) (West 2005)).

${ }_{145} I d . \S 402(\mathrm{a})(1), 116$ Stat. at 112.

146540 U.S. 93, 188-89 (2003).

147 Bipartisan Campaign Reform Act $\S 307(a)(1), 116$ Stat. at 102 (codified at 2 U.S.C.A. $\S$ $441 \mathrm{a}(\mathrm{a})(1)(\mathrm{A}))$.

${ }_{148}$ Id. $\S 323(\mathrm{a})-(\mathrm{b}), 116$ Stat. at 82 (codified at 2 U.S.C.A. $\S 441 \mathrm{i}$ ) (requiring political committees to follow the monetary limitation for contributions in the Act). Specifically, the BCRA limited an individual's aggregate contribution to $\$ 37,500$ for candidates and their committees and $\$ 57,500$ for all other types of contributions. Id. § 307(b), 116 Stat. at 102-03 (codified as amended at 2 U.S.C.A. § 441a(a)(3)).

149 Jeffery Milyo, The Political Economics of Campaign Finance, 3 IndeP. REv. 537, 544 (1999), available at http://www.independent.org/pdf/tir_03_4_milyo.pdf (discussing trends in voter turnout as related to campaign spending for various types of elections). 
TABLE 5

Campaign Expenditures in U.S. House and Senate Campaigns, Presidential Election Years ${ }^{150}$

\begin{tabular}{|l|l|c|l|}
\hline Year & $\begin{array}{c}\text { Total dollars } \\
\text { spent (2002 } \\
\text { dollars) }\end{array}$ & $\begin{array}{c}\text { Voter turnout } \\
\text { (adjusted for } \\
\text { 2002 voter } \\
\text { registration) }\end{array}$ & $\begin{array}{c}\text { Votes per } \\
\text { dollar } \\
\text { spent }\end{array}$ \\
\hline 1976 & $\$ 309,375,000$ & $106,919,135$ & 0.346 \\
\hline 1980 & $\$ 417,706,446$ & $105,496,502$ & 0.253 \\
\hline 1984 & $\$ 553,907,457$ & $102,279,658$ & 0.185 \\
\hline 1988 & $\$ 618,600,300$ & $98,956,292$ & 0.160 \\
\hline 1992 & $\$ 637,897,436$ & $105,649,989$ & 0.166 \\
\hline 1996 & $\$ 715,896,552$ & $96,857,224$ & 0.135 \\
\hline 2000 & $\$ 886,197,917$ & $104,300,496$ & 0.118 \\
\hline
\end{tabular}

TABLE 6

Campaign Expenditures in U.S. House and Senate Campaigns, Midterm Election Years ${ }^{151}$

\begin{tabular}{|l|l|l|l|}
\hline Year & $\begin{array}{c}\text { Total dollars } \\
\text { spent (2002 } \\
\text { dollars) }\end{array}$ & $\begin{array}{c}\text { Voter turnout } \\
\text { (adjusted for } \\
\text { 2002 voter } \\
\text { registration) }\end{array}$ & $\begin{array}{c}\text { Votes per } \\
\text { dollar } \\
\text { spent }\end{array}$ \\
\hline 1978 & $\$ 426,388,889$ & $79,533,230$ & 0.187 \\
\hline 1982 & $\$ 533,507,393$ & $81,684,886$ & 0.153 \\
\hline 1986 & $\$ 655,829,152$ & $74,486,037$ & 0.114 \\
\hline 1990 & $\$ 533,780,822$ & $76,766,507$ & 0.144 \\
\hline 1994 & $\$ 714,536,585$ & $80,935,063$ & 0.113 \\
\hline 1998 & $\$ 674,076,923$ & $75,510,851$ & 0.112 \\
\hline 2002 & $\$ 770,180,000$ & $78,390,424$ & 0.102 \\
\hline
\end{tabular}

Two adjustments are made to the data: the Consumer Price Index ${ }^{152}$

\footnotetext{
${ }^{150}$ Data on file with author.

151 Data on file with author.

152 U.S. Dep't of Labor, Bureau of Labor Statistics, Consumer Price Indexes, http://www.bls.gov/cpi (last visited Jan. 6, 2006) (providing a hyperlink to an "Inflation
} 
is used to adjust dollar figures for inflation, ${ }^{153}$ and Census Bureau data is used to adjust voter turnout data for growth in the votingage population. ${ }^{154}$

Certainly, the nature of campaign spending has changed dramatically during this period. To reach voters, politicians have used buttons, signposts, bumper stickers, radio and television advertising, telephone solicitations, and internet advertising. This is no different from fishing; different fishing technologies have made fishing more efficient and more destructive over time. Similarly, television and internet access have clearly been great technological advances, but overuse of these technologies for campaign advertising has likewise reduced their usefulness.

There are clearly similarities between this data and that shown in Table 4 for halibut fishing. As with the data on pounds of halibut landed, there is no clear downward trend in voter turnout over time which might lead some to discount the importance of the problems. In both data sets, however, there is an observable upward trend in expenditures, and an observable downward trend in efficiency, as measured by catch per skate and by votes per dollar. The data from Tables 5 and 6 are set out in Figure 5. The halibut fishing data from Table 4 is set out in Figure 6.

Calculator" to convert past dollar buying power into current dollar buying power).

153 The direct contribution limit under FECA remained at $\$ 1,000$ for the entire period between 1978 and 2002. 2 U.S.C.A $\S 431(8)(B)(i)-(i v)$ (West 2005). Therefore, an argument could be made that no adjustment for inflation should be made at all. Not adjusting for inflation would render the argument in this article stronger.

${ }_{154}$ Estimates on the number of voting-age Americans, and data on voter registration are compiled from the Census Bureau. U.S. Census Bureau, Current Population Survey, NOVEMBER 2004 AND EARLIER REPORTS, available at http://www.census.gov/population/ socdemo/voting/tabA-1.xls (last visited Feb. 4, 2005). 
2005]

FIGURE 5

Votes Per Dollar Spent

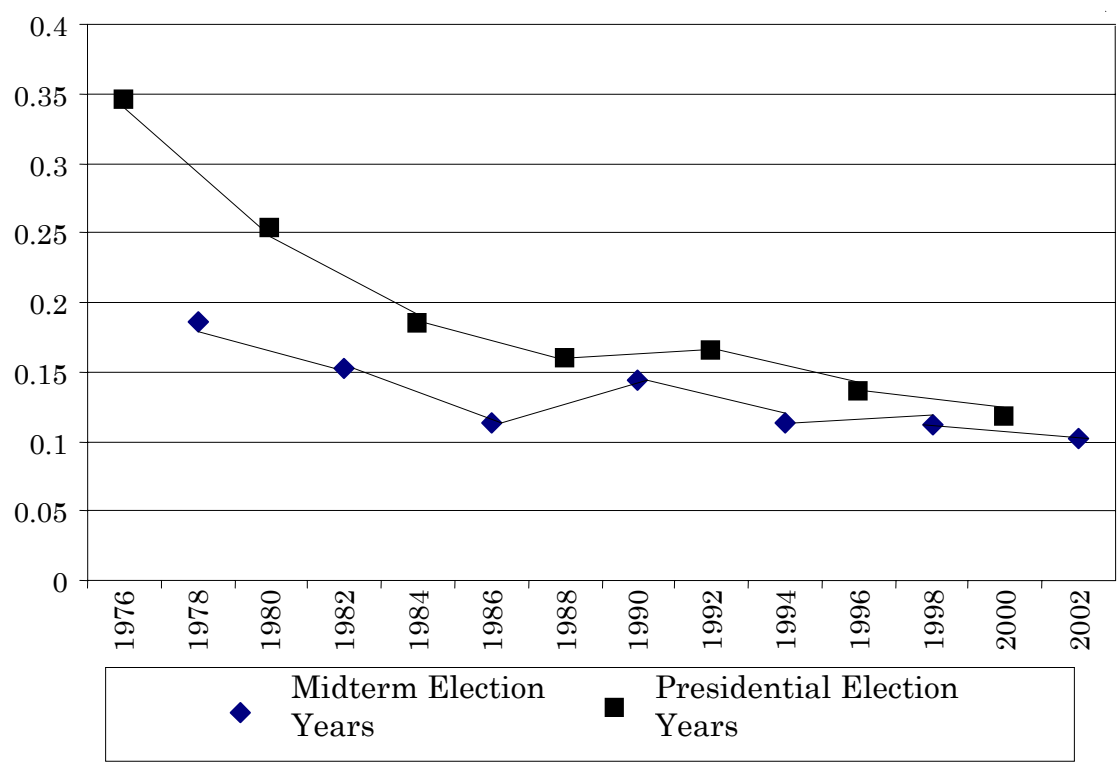

FIGURE 6

Pacific Halibut Catch Per Skate (lbs/skate)

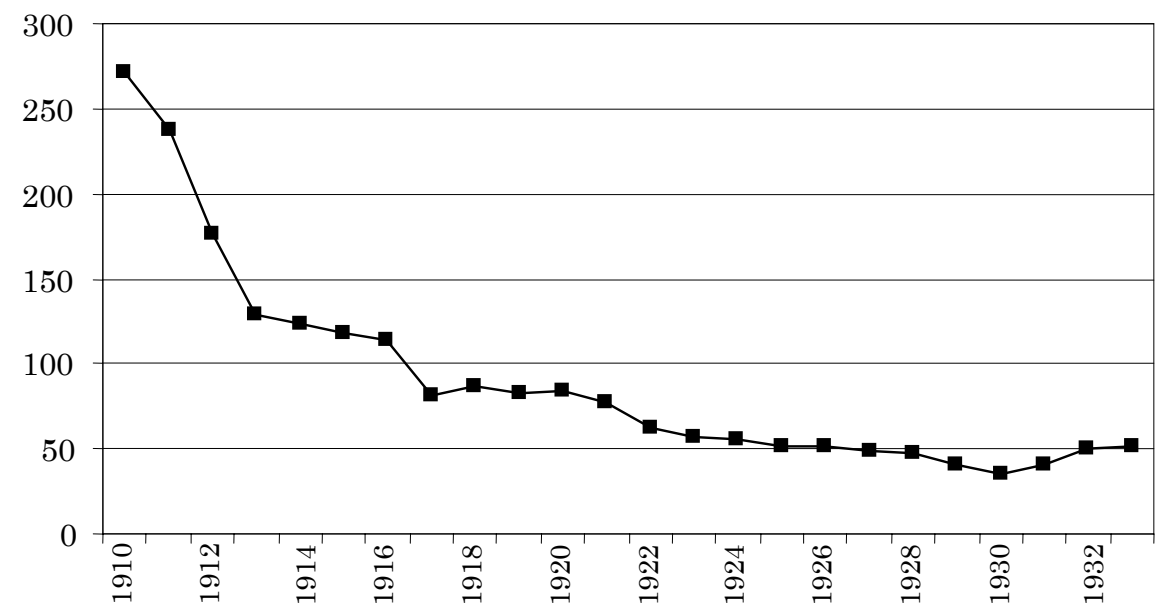


Although the similar downward trends in campaign spending efficiency and fishing efficiency are obvious, there are a number of possible explanations for this trend in campaign expenditure efficiency, other than the existence of an inexorable tragedy of the commons. Given the small number of observations, it is impossible to conclusively test a hypothesis concerning the causes of decreasing campaign spending effectiveness. The data from presidential-year and midterm-year elections, however, can be pooled using a dummy variable to capture the differential effects, and the resulting fourteen observations will permit us to at least entertain some suggestions.

One alternative explanation is that increasing income has led to more disposable income which can be used to fund campaigns; this leads to more money being pumped into the political campaign effort. If this were true, then there is no market failure because increased campaign spending is simply a reflection of this particular effect of greater disposable income.

Another alternative explanation is that increased campaign spending is simply due to increased advertising expenditures. It could be that political candidates are simply spending more money because it takes more to compete with potato chip commercials or automobile commercials. This does not, however, necessarily preclude a tragedy of the commons explanation; it may simply reflect the possibility that campaign speech and advertising are all caught up in a tragedy of the commons.

Another possible alternative is that increased competitiveness of certain races has accentuated their importance, and led to an infusion of money into these races. Statistical analysis of this hypothesis seems to point the other way. In the econometric model that is described below, various models were estimated using a variable to measure the competitiveness of congressional races. In no estimation did the competitiveness variable yield a statistically significant relationship. Moreover, other available evidence suggests that federal campaigns have become less competitive, not more; incumbency re-election rates have been increasing for decades. ${ }^{155}$

Another possible alternative explanation is that voters have been

${ }^{155}$ Alan I. Abramowitz et al., Incumbency, Redistricting, and the Decline of Competition for U.S. House Elections, http://www.emergingdemocraticmajorityweblog.com/spsa/spsa.html (last visited Jan. 6, 2006); REDISH, supra note 127, at 36; PAUL S. HERRNSON, CONGRESSIONAL EleCtions: CAMPAigning AT Home AND IN Washington 28-34 (2004); John A. Ferejohn, On the Decline of Competition in Congressional Elections, 71 AM. PoL. SCI. REV. 166, 166 (1977). 
turned off by a number of factors other than campaign spending. One might argue, for example, that an increase in political partisanship has soured voters and caused them to turn out in lower numbers. This theory, however, runs counter to the evidence available; political party identity seems to be on the decline. ${ }^{156}$ If one takes party loyalty as a measure of partisanship, then one can say that partisanship has been decreasing, not increasing, over time.

Although there are many possible alternatives to the decrease in campaign spending effectiveness, some scholars have developed theories that explain the overall growth of campaign spending. Professor John Lott has empirically tested the hypothesis that the growth in the size of government has accounted for the growth in the amount of campaign spending. ${ }^{157}$ This hypothesis is not inconsistent with the hypothesis advanced in this Article. To the extent that Lott is claiming that there are increasing favors to be gotten from helping to fund elections, and that this has led to increasing attempts to curry favor with aspiring politicians, ${ }^{158}$ it is only natural that voters would be disillusioned with the degree of campaign spending, recognizing it for what it is: a symptom of the growing influence of money over political institutions. Lott's prescription, to shrink the size of government, is not necessarily inconsistent with prescriptions for solving the tragedy of campaign spending commons, though Lott is clear in his conviction that any other prescription would merely be addressing symptoms and not root causes. ${ }^{159}$ The suggestive findings in this Article are not inconsistent with those of Lott's.

A test for the effect of a tragedy of the commons can be accomplished by regressing the reciprocal of campaign spending efficiency-dollar spent per vote for U.S. House and Senate campaigns-against a simple time trend variable, the election year. The general form of the model estimated is:

${ }^{156}$ See, e.g., Russell J. Dalton, The Decline of Party Identifications, in PARTIES WITHOUT Partisans: Political Change in Advanced Industrial DeMOCRACies 19, 22-23 (Russell J. Dalton \& Martin P. Wattenberg eds., 2000).

${ }^{157}$ See generally John R. Lott, Jr., A Simple Explanation for Why Campaign Expenditures Are Increasing: The Government is Getting Bigger, 43 J. L. \& ECON. 359 (2000) (discussing how higher government spending, as a result of larger government, causes increases in campaign expenditures).

${ }^{158}$ Id. at 363.

${ }^{159}$ Id. at 360. Lott warns that attempting to restrict contributions would simply force would-be contributors to substitute in-kind contributions for monetary donations. Id. at 362 . 
Campaign Expend $/$ Vote $=\beta_{0}+\beta_{1}$ PresDummy $+\beta_{2}$ Year + $\beta_{2} \ln G D P+\beta_{3} \ln$ Ad Expenditures.

The dependent variable is thus the reciprocal of the campaign spending efficiency. PresDummy is a dummy variable indicating an election taking place in a presidential election year. GDP is per capita income, in 2000 dollars, ${ }^{160}$ and Ad Expenditures is the total amount of money spent nationally on advertising, also adjusted for inflation. ${ }^{161}$ I used the natural logarithm for these two variables. ${ }^{162}$ Therefore, a positive coefficient on the year variable represents the decreasing effectiveness, over time, of campaign spending. As noted above, I also estimated models that included a variable to measure competitiveness of congressional races. A statistically significant relationship may suggest that increased campaign spending is the result of more races being competitive. The variable I used was the percentage of races in which the winning margin was below a certain threshold. I used thresholds of $5 \%, 7.5 \%$, and $10 \%$. None of these cases yielded a variable with any statistical significance. Since this competitiveness variable did not contribute to explanatory power, it was omitted from other estimations. The results of the estimated models are shown in Table 7 below.

${ }^{160}$ The GDP in 2000 dollars may be obtained from a website provided by Economic History Services. Economic History Services, What Was The GDP Then?, http://www.eh.net/hmit/gdp (last visited Jan. 30, 2005) (providing GDP information from and citing to Louis Johnston \& Samuel H. Williamson, The Annual Real and Nominal GDP for the United States, 1789Present (2004)).

${ }^{161}$ National advertising data is obtained from RoBERT J. COEN, UNIVERSAL MCMANN, INSIDER's REPORT: ROBERT COEN PRESENTATION ON ADVERTISING EXPENDITURES (June 2005), available at http://www.universalmccann.com.

${ }_{162}$ A Box-Cox test indicated that a linear model might also provide a fit, but empirically, the log-linear models provided slightly more predictive models. A Box-Cox linearity plot is often used to transform the $\mathrm{X}$ variable, which can help to improve the linear fit between $\mathrm{X}$ and Y. NIST/SEMATECH, ENGINEERING STATISTICS HANDBOOK § 1.3.3.5, available at http://www.itl.nist.gov/div898/handbook/eda/section3/boxcoxli.htm (last visited Oct. 3, 2006). 
TABLE 7

Dependent variable: Campaign Expenditures/Vote

\begin{tabular}{|c|c|c|c|c|}
\hline & $\begin{array}{l}\text { Model } 1 \\
\text { Year only }\end{array}$ & $\begin{array}{c}\text { Model } 2 \\
\text { Advertising } \\
\text { only }\end{array}$ & $\begin{array}{l}\text { Model } 3 \\
\text { GDP only }\end{array}$ & $\begin{array}{c}\text { Model } 4 \\
\text { All }\end{array}$ \\
\hline $\mathbf{R}^{2}$ & 0.90 & 0.93 & 0.89 & 0.96 \\
\hline $\begin{array}{c}\text { Adjusted } \\
\mathbf{R}^{2}\end{array}$ & 0.88 & 0.92 & 0.87 & 0.94 \\
\hline Intercept & $\begin{array}{l}-369.6 \\
(-7.90)\end{array}$ & $\begin{array}{c}-61.8 \\
(-8.92)\end{array}$ & $\begin{array}{c}-86.9 \\
(-7.20)\end{array}$ & $\begin{array}{l}-422.4 \\
(-2.26)\end{array}$ \\
\hline $\begin{array}{c}\text { Presidential } \\
\text { Election } \\
\text { Dummy }\end{array}$ & $\begin{array}{c}-1.73 \\
(-4.57)\end{array}$ & $\begin{array}{c}-1.78 \\
(-5.73)\end{array}$ & $\begin{array}{c}-1.77 \\
(-4.56)\end{array}$ & $\begin{array}{c}-1.76 \\
(-6.42)\end{array}$ \\
\hline Year & $\begin{array}{l}0.190 \\
(8.07)\end{array}$ & & & $\begin{array}{l}0.250 \\
(2.04)\end{array}$ \\
\hline $\begin{array}{c}\ln \text { Ad } \\
\text { Expend }\end{array}$ & & $\begin{array}{c}5.77 \\
(10.06)\end{array}$ & & $\begin{array}{l}10.84 \\
(3.45)\end{array}$ \\
\hline ln GDP & & & $\begin{array}{c}9.27 \\
(7.85)\end{array}$ & $\begin{array}{l}-20.96 \\
(-2.30)\end{array}$ \\
\hline
\end{tabular}

$\mathrm{N}=14$; t-statistics in parentheses.

With just 14 observations, these results can only be considered suggestive. But the signs of coefficients rarely switch, and the coefficient for the dummy for presidential election years is very consistent. These results point us towards some interesting 
inferences. First, the time trend variable is positive and significant, and the coefficients of similar magnitude in both models 1 and 4 indicate that we may at least entertain the suggestion that declining efficiency over time is indicative of a tragedy of the commons pattern of campaign fundraising and spending. Second, the best explanatory variable is $\ln A d$ Expenditures. Does this suggest that campaign spending has been increasing only because general advertising expenditures are increasing? This is possible, but if true, would not render less plausible the hypothesis that campaign spending efficiency is a tragedy of the commons. It would be entirely consistent to offer a complementary hypothesis that advertising spending in general follows a tragedy of the commons pattern. Since private rents from advertising are so high, however, this is likely to be tolerated for a longer time by private advertising spenders.

It is interesting to compare these results with those obtained by Lott. Using a slightly different specification, Lott found a highly significant relationship between campaign spending and government size, but Lott's regressions also found a significant time trend relationship. ${ }^{163}$ Since Lott's regressions were simply trying to control for time-sensitive effects, he did not comment on the significance of his time trend variable. ${ }^{164}$

I am not prepared to make the strong claim that I have proven that the tragedy of the commons fully explains spiraling campaign spending. Strictly speaking, this latter proposition would be difficult to conclusively prove, requiring the rejection of all other possible and incompatible explanations. The combination of anecdotal evidence and the statistical inferences in this case, however, should give us reason to consider the possibility carefully. Does a tragedy of the commons explanation seem more or less likely than the alternative explanations? Does it ring true that we are pouring money into campaigns, and candidates are pouring effort into fundraising and spending simply because we are wealthier and can afford it? Perhaps spiraling advertising costs are to blame, representing its own tragedy of the commons that has spilled over into the political arena. But in all of the hand-wringing by politicians and by pundits and concerned citizen groups over campaign spending, not one, to my knowledge, invokes increased advertising expenses as the root cause of spiraling campaign

163 Lott, supra note 157, at 381, 383.

${ }^{164} I d$. at $383 \mathrm{n} .44,384$ (focusing his analysis on the budget expenditure variables). 
spending.

Future research may involve data in which the time trends in GDP data or advertising data can be separated out. In the meantime, we should be willing to acknowledge that perhaps we are facing too much campaign speech and too much campaign spending. Ultimately, our political candidates do not benefit from unfettered rights to raise and spend money.

\section{Is U.S. Campaign Spending "Excessive"?}

In order for campaign spending to be a tragedy of the commons problem, campaign spending must be excessive in the way that halibut fishing was excessive and unsustainable. Many scholars in the field of campaign finance balk at the suggestion that campaign spending and concomitant campaign advertising is in any sense of the word "excessive." The problem with campaign spending, as Professors Bruce Ackerman and Ian Ayres have argued, is that most campaigns are underfinanced, and not overfinanced. ${ }^{165}$ As Ackerman and Ayres note, campaign expenditures for the 2000 election cycle totaled $\$ 3$ billion, while in 1999 automobile advertisement expenditures alone totaled $\$ 13$ billion, and total TV advertising expenditures totaled $\$ 66$ billion. 166 Critics of campaign finance reform, of course, chime in with more examples of expenditures on trivial goods and how they dwarf political campaign expenditures. ${ }^{167}$

In terms of raw spending amounts, perhaps Ackerman and Ayres are right in arguing that $\$ 3$ billion is too small a sum to be spending on a matter far more important than the type of automobiles we buy, or the sum total of all the other fairly trivial consumer expenditure decisions we make that result in the spending of $\$ 66$ billion in advertising per year. The conclusion, however, must be

165 Bruce Ackerman \& IAN Ayres, Voting With Dollars: A NeW Paradigm for CAMPAIGN FINANCE 85 \& 261 n.27 (2002) (citing a study by fourteen campaign finance experts for the proposition that Americans are not spending "too much' on political campaigns"); see also TASK Force on CAMPAIGN REFORM, WoOdRow Wilson SCH. OF PUb. \& INT'L AfFAIRS, PRINCETON Univ., CAMPAign Reform: Insights AND Evidence (1998) (stating "one of the primary problems with the current American system of campaign finance is not too much spending, but too little"), available at http://www.wws.princeton.edu/ lbartels/ campaignreform; Richard Briffault, Reforming Campaign Finance Reform: A Review of Voting With Dollars, 91 CAL. L. REV. 643, 647-48 (2003) (stating that public funding for presidential candidates is underfunded and most jurisdictions lack funding for congressional candidates).

166 ACKERMAN \& AYRES, supra note 165 , at 85.

${ }^{167}$ See, e.g., SMITH, supra note 122, at 42 (noting that Americans spend two to three times more on potato chips than on political campaigns). 
more nuanced than that. Ackerman and Ayres fully recognize that the problem is the taint of the money that is used to fund these campaign expenditures-hence their ingenious proposal to establish a secret donation booth for campaign donations, funded by government-provided "Patriot" dollars. ${ }^{168}$

Thus, more spending on campaign speech is not necessarily bad, provided that it is funded by the right type of sources. The amount of campaign speech and spending of the nature currently predominant, however, is not a good or effective thing, precisely for the reasons that Ackerman and Ayres and others have recognized: the lack of credibility associated with campaign speech that seems too closely tied to unseemly interests. Additionally, John Lott's argument that campaign expenditures are rising because of the growth of federal and state government seems to concede that voters view money as a corrupting influence, since this causal relationship implies a quid pro quo in large campaign contributions by large donors.

An economic analysis illustrates this point. Ackerman and Ayres lament that campaign spending is less than one-fourth of spending on automobile advertisements. This is exactly what we would expect, however. Automobile advertising is a private good, as opposed to the public good of campaign speech; at least that is what the pretense is. Assuming that auto advertising and the campaign advertising expenditures can be modeled as declining-marginal benefit enterprises with constant marginal costs (as Gordon modeled overfishing) ${ }^{169}$ a comparison of the two markets reveals that the higher marginal and average products of auto advertising, owing to the private nature of its rents, is higher than that of campaign advertising. This is shown in Figure 7.

\footnotetext{
168 ACKERMAN \& AYRES, supra note 165, at 25-31, 95-97.

169 See supra Figure 4 and accompanying text.
} 
FIGURE 7

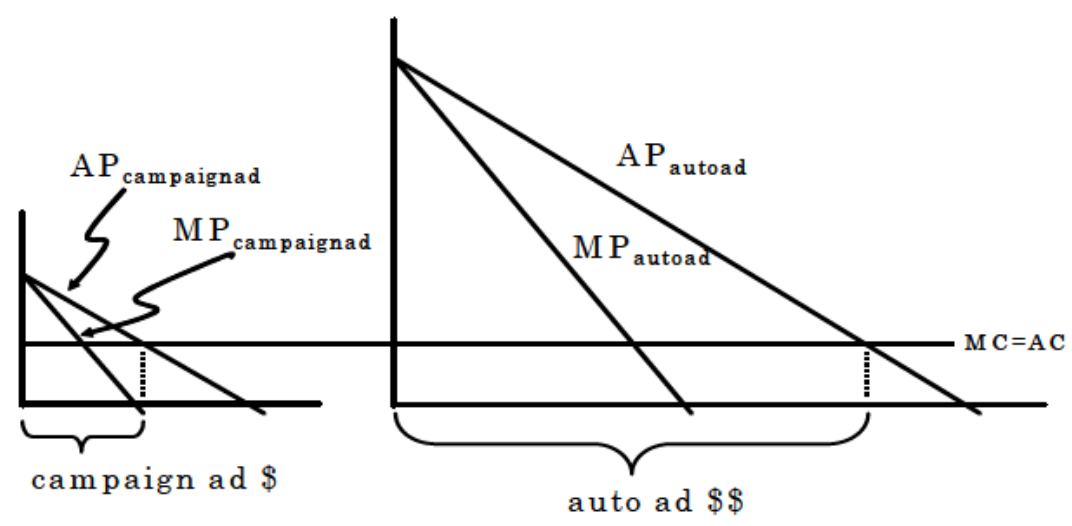

We expect auto advertisements to be more frequent because auto manufacturers are expected to appropriate the rents from auto advertising. An idealistic voter, however, does not expect campaign advertising to be very high; she does not expect that campaign advertising yields a result that inures to the private benefit of the campaigning politician. The involvement, however, of quid pro quos with the campaign donations ${ }^{170}$ results in an expectation that the level of campaign spending will rise, concomitant with the higher average and marginal product of campaign advertising. Marginal and average products of advertising are no longer low; there is a generous private benefit that inures to the campaigning politiciana secure job ${ }^{171}$ of relative wealth and power in the United States

${ }^{170}$ Much has been written on whether there is a causal connection between political contributions and voting patterns of recipients. See, e.g., Stephen G. Bronars \& John R. Lott, Jr., Do Campaign Donations Alter How a Politician Votes? Or, Do Donors Support Candidates Who Value the Same Things That They Do?, 40 J.L. \& EcoN. 317 (1997); Thomas Stratmann, What Do Campaign Contributions Buy? Deciphering Causal Effects of Money and Votes, 57 S. EcoN. J. 606 (1991); Thomas Stratmann, Are Contributors Rational? Untangling Strategies of Political Action Committees, 100 J. PoL. EcoN. 647 (1992); Henry W. Chappell, Jr., Campaign Contributions and Congressional Voting: A Simultaneous Probit-Tobit Model, 64 REV. EcoN. \& Stat. 77 (1982); W.P. Welch, Campaign Contributions and Legislative Voting: Milk Money and Dairy Price Supports, 35 W. PoL. Q. 478 (1982). Suffice it say, however, the perception that there is a quid pro quo is harmful enough to the electoral process.

171 Spending ratios of more than 3.5:1 and 2:1 between incumbents and challengers in the 2000 House and Senate elections are blamed on campaign finance reform. JOSEPH E CANTOR, CRS Issue BRIEF For Congress, CAMPAign Financing 4 (2003) available at http://fpc.state.gov/documents/organization/28105.pdf. With respect to such imbalances, numerous theories pertaining to redistricting activities have been put forth. See, e.g., Andrew 
Congress. The higher level of campaign advertising is thus a signal to the voter that average productivity of campaign dollars has increased, and that unsavory, if perfectly legal, funding sources are involved.

The Ackerman and Ayres proposal to attempt to infuse campaign speech with more frequent speech, more meaningful speech, and less cynical perceptions on the part of voters is an ingenious one. Like most public funding proposals, they attempt to infuse campaign dollars into those campaigns that need and deserve it the most-those meritorious yet underfunded candidates that face a political machine with generous private funding sources that benefit from the incumbent's power. At the same time, it raises the bar for private giving to incumbents with less noble motivations for seeking and maintaining public office, such as a payback position upon retirement. ${ }^{172}$ The dual effects of this proposal are to subsidize those for whom campaign spending tends to be too low and discourage giving to those for whom campaign spending tends to be too lavish, while at the same time flattening differences in spending between well-endowed and poorly-endowed candidates without utilizing a command-and-control type of public financing system that most reformers advocate. Essentially, the Ackerman and Ayres proposal provides the advantage of not having any governmental funding decisions at all.

This proposal, however, does not say that campaign spending is too low and thus not a tragedy of the commons. Rather, it is an acknowledgement that some form of public funding of political campaigns would serve to improve the efficiency of campaign dollars spent. That is, it could be that campaign speech is only excessive because it is perceived by the voter to be tainted. The presence of the taint is what renders current levels of campaign speech excessive. Ackerman and Ayres' proposal to remove the taint by way of a form of public financing - a form that engages the public by involving it with distributional decisions-is thus aimed at flipping the campaign speech world from the incredible to the credible, but it does not, in the long run, relieve the candidates and the public from

Gelman \& Gary King, Enhancing Democracy through Legislative Redistricting, 88 AM. POL. SCI. REV. 541, 542-43 (1994); Abramowitz et al., supra note 155; see also supra note 155 and accompanying text (discussing the rise in incumbency re-election rates).

172 Billy Tauzin retired in 2004 after twelve terms as a Congressman to head up the Pharmaceutical Research and Manufacturers of America, a drug industry trade group, a position for which he will receive a $\$ 2$ million salary. Sheryl Gay Stolberg, Washington Talk; Lawmaker's Plans to Lobby Raises Issue of Crossing Line, N.Y. TIMES, Feb. 7, 2004, at A12. 
the inexorable push to engage in a fundraising and spending derby. Indeed, it is possible that we would find, contrary to Ackerman and Ayres' suspicions, that less money is required to launch an effective campaign once the taint of money is removed.

\section{Why Don't Resource Users Want to Be SAVED From THEMSELVES?}

The most interesting question raised by true tragedies of the commons is why it has proven so difficult to save resource users from their own self-destructive behavior. In many cases, it is a simple problem of the prohibitive transaction costs of cooperation, especially in large, atomistic groups of resource users. This would include the costs of enforcement, and the risks that enforcement would be ineffectual. But in too many instances to be dismissed, transaction costs are not prohibitive, can be overcome, and clearly do not represent the obstacle to cooperation. The question in these cases is, if resource users benefit from limits on their own behavior, why don't resource users demand regulation?

In some instances, they do. In The Theory of Economic Regulation, Stigler illustrated how some regulated industries came about by the co-option of government by industries seeking protection from new entry and competition. ${ }^{173}$ A less cynical view of Stigler's theory might be that resource users sought the government's "coercive" powers to arrest wasteful overexploitation. ${ }^{174}$ In other instances, even in the absence of governmental regulation, resource users coordinate behavior to avoid wasteful overexploitation as studied by Elinor Ostrom and others. ${ }^{175}$ Nonetheless, the reality is that often the tragedies of the commons are not solved despite the obvious and sometimes huge gains to be had.

Economists have some difficulty explaining the persistence of tragedies of the commons that remain unsolved by coordination or regulation. Explaining this persistence seems to require some relaxation of assumptions of rationality, and some concessions to behavioral economists. Professor Barton Thompson has applied behavioral psychology literature to environmental tragedies of the

${ }^{173}$ George J. Stigler, The Theory of Economic Regulation, 2 BeLl J. ECON. \& MGMT. SCI. 3, 3-6 (1971).

${ }^{174}$ Stigler's view of government and rent-seeking by regulated industries was based upon the one thing government can offer industries: its "power to coerce." Id. at 4.

175 See generally OsTROM, supra note 2. 
commons, most notably to the tragedies of overfishing and groundwater overdrafting. ${ }^{176}$ Thompson attempted to explain why so many environmental tragedies of the commons have remained unresolved, and why, given the tremendous potential gains, we do not see more cooperation or regulation. ${ }^{177}$ Thompson has found much of the answer to be that resource users harbor a variety of pathologies causing them to oppose any sort of cooperative or regulatory arrangement that would extricate them from their particular tragedy. ${ }^{178}$ Roughly, the pathologies fall into three categories: the difficulty of giving up perceived rights, self-serving notions of fairness, and undue optimism. ${ }^{179}$

In the case of fisheries, fishermen, like most other people, are inherently skeptical when asked to surrender a current right in exchange for a future benefit even if the potential advantage is immense. ${ }^{180}$ Thus, curtailing fishing effort, even if the benefit would be a healthier stock to fish in the future, is viewed as a sacrifice even if the net result is a gain. It could be, as Thompson argues, that people simply frame gains and losses differently, discounting future gains relative to current losses. ${ }^{181}$ Or it could be that an "endowment effect"182 causes people to hold onto their perceived entitlements with irrational stubbornness.

Transportation planners would sympathize with this dilemma because in solving traffic problems, they must deal with drivers who want traffic problems solved without giving up their right to drive. There is a reason that the most popular solutions involve more government provisions, such as more roads or more subsidization of transit services, and rarely impose any costs upon drivers. ${ }^{183}$ One study found that some drivers even resent high-occupancy vehicle lanes as "special treatment" for other drivers, failing to recognize that they could pick up a passenger and become eligible themselves. ${ }^{184}$

176 Thompson, supra note 35, at 256-62.

177 Id. at $256-57$.

178 Id. at $260-62$.

179 Id. at $258-65$.

180 Id. at 256 (asserting that most proposed solutions to commons tragedies, such as caps on use, are viewed as current losses rather than long-term gains).

${ }^{181}$ Id. at $256-57$.

182 See Thaler, supra note 56, at 44 (1980).

183 Legislatures have typically indulged constituents by offering tax incentives rather than taxes to curb externality-imposing activities like driving. Maureen B. Cavanaugh, On the Road to Incoherence: Congress, Economics, and Taxes, 49 UCLA L. REV. 685, 688 (2002).

${ }^{184}$ Strahilevitz, supra note 75, at 1239. 
Fixing resource and environmental problems often requires an allocation of burdens. This task engenders self-serving "egocentric interpretations of fairness" which inhibit agreements that must be made before getting to the solutions. ${ }^{185}$ Cooperation to solve even the most pressing problems is elusive. Canada's Pacific halibut fishery provides a case in point. The fishery had become overfished as early as 1980, giving rise to economist Peter Pearse's prescription of adopting an individual transferable quota program to curb overfishing. ${ }^{186}$ The fishermen themselves recognized the need to adopt an individual transferable quota program, but could not agree on an initial allocation of the quota. ${ }^{187}$ Only an ultimatum by the Department of Fisheries and Oceans, who threatened to impose much more draconian measures, brought the fishermen back to the bargaining table, from which they eventually emerged with an agreement on how to allocate the quota. ${ }^{188}$

The human propensity to blame also plays into this fairness pathology and has a role in preventing cooperation. Fishing industries and fishing communities have trouble refraining from overfishing and have trouble agreeing on a cooperative solution because they remain fixated on the role that others have had in contributing to the problem. ${ }^{189}$ Even if cooperation and sacrifice are in the best interests of the resource users, it has often proven to be too galling to undertake if they harbor a perception, accurate or not, that someone else's behavior was to blame for the problem in the first place. ${ }^{190}$

Finally, resource users deal with uncertainty in ways that are not conducive to conservation or cooperation. When faced with even the smallest of short-term sacrifices, people have an amazing capacity to project incredible optimism with respect to scientifically

\footnotetext{
185 Thompson, supra note 35, at 260.

186 See Comm'n on Pac. Fisheries Policy, Can. DeP'T of Fisheries and Oceans, Turning THE TIDE: A NEW Policy For CANADA'S PACIFIC FIsheries 121-25 (1982). Individual quota programs regulate fishing by licensing fishing to a specified quantity per quota. The quantity-based license cures the incentive to overfish in order to maximize profits by limiting the total possible catch. Furthermore, the transferability motivates less efficient fishermen to exit the fishery, which alleviates the overcapitalization problem. See Shi-Ling Hsu \& James E. Wilen, Ecosystem Management and the 1996 Sustainable Fisheries Act, 24 ECOLOGY L.Q. 799, 807-09 (1997).

187 Suzanne IUdicello et AL., Fish, Markets, and Fishermen: the Economics of OVERFISHING 148-49 (1999).

${ }^{188} I d$. at 149.

189 Thompson, supra note 35, at 261.

190 Id. at 262 .
} 
uncertain outcomes. ${ }^{191}$ Fishermen seem to have a penchant for adopting the most optimistic estimates of fish stocks. ${ }^{192}$ Moreover, people seem to be more confident than their abilities warrant. In the case of fishermen, regulation is often resisted because they cherish the opportunity to compete against each other, ${ }^{193}$ many of them because they harbor an elevated perception of their fishing skills vis-à-vis other fishermen. ${ }^{194}$ In short, uncertainty is almost never resolved in a way that invites cooperation or regulation.

All of these propensities are, in some sense, pathological. But for even the casual observer of human nature, these explanations of why people ignore their own long-term interests ring remarkably true. People often very strongly prefer the broken system they know, to the quite possibly superior system they do not know, even if they recognize that they are trapped in a tragic spiral.

Campaign finance and spending reform has been hostage to the same fears of the unknown. Campaigning politicians are loath to give up the freedom to spend more time raising money and to spend more money in a campaign. Similar to the fishermen discussed above, campaigning politicians blame everyone but themselves for their current plight, further inhibiting the search for solutions. Given the nature of those seeking elected office, one would not be surprised to learn that campaigning politicians invariably think they can better their opposition at fundraising.

Opposition to the BCRA provides an example. The problems targeted by the BCRA are different from the overspending problem discussed above, but the soft money problem targeted by the BCRA has its own tragedy of the commons dynamic. The upward spiraling importance and quantity of soft money in politics gives rise to tragic dynamics similar to those described above. Not only politicians but also interest groups faced with increasing soft money expectations should have seen merit in regulation. And yet opposition to the BCRA was widespread among interest groups, including the AFLCIO, ${ }^{195}$ the American Civil Liberties Union, the National Right to Life Committee, the Christian Coalition, the American Heart

\footnotetext{
191 Id. at $258-65$.

${ }^{192} I d$. at 258 ("If scientists estimate that there are between one thousand and thirty thousand fish in any given population, most fishermen assume that there are thirty thousand fish in that population.").

${ }^{193} I d$. at 245.

194 Id. at 244.

195 William O'Rourke, Editorial, Grieving Democrats Quietly Fade Into Insignificance, CHI. Sun-Times, Mar. 27, 2001, at 33.
} 
Association, and various chambers of commerce, just to name a few of the strange bedfellows. ${ }^{196}$ Congressional campaigners, presumably the beneficiaries of regulation that would limit the amount of soft money fundraising they would have to conduct, have themselves been extremely critical of election financing. ${ }^{197}$ Congressman Albert R. Wynn (D-MD), an African-American, opposed the BCRA because he believed that the soft money ban would impair the ability of black candidates and elected black representatives to fund "get-out-the-vote" drives and voter registration activities. ${ }^{198}$ He maintains this view despite the reality that the overwhelming majority of soft money is contributed by regulated industries to further their economic interests, ${ }^{199}$ thus conferring substantially more advantages on white candidates than black candidates. ${ }^{200}$ On the other side of the aisle, Republicans opposed the bill because of its lack of prohibitions on labor union activity in soliciting soft money for party activities; ${ }^{201}$ this, despite the widely held belief that a ban on soft money would amplify their advantage in hard money donations over the Democrats. ${ }^{202}$ At every turn, opposition to the BCRA has come from those with worst-case suspicions of how the legislation would work to their detriment.

And yet, some have recognized the need for mutual coercion. Former Senator Zell Miller wrote in an op-ed about his support for the BCRA:

Make no mistake about it: When it comes to winning political races by raising millions of dollars and buying lots of TV time, I'm as competitive as they come. I've done it three times in a row now-once for the Senate and twice for governor-and it's the formula for success in politics today. But frankly, it's a rotten formula, and the rules of this game

196 Vanessa Blum, Senate Showdown: Battle Shifts on Finance Reform, LEGAL TIMEs, Mar. 19, 2001, at 1, 14 .

197 Paul S. Herrnson, Congressional Elections: CAmpaigning at Home and in WASHINGTON 284 (2004).

${ }^{198}$ Interview by Kwame Holman with Representative Albert R. Wynn (D-MD), Debating Reform (July 11,2001), http://www.pbs.org /newshour/bb/congress/july-dec01/cfr-a_7-11.html (last visited October 3, 2005).

199 HERRNSON, supra note 197, at 295 .

$200 I d$. at $285,295$.

201 Joe Salkowski, Senate Poised To Pass Reform Measure Today, ARIZ. DAILY STAR, Apr. 2, 2001, at 1 ("Other Republicans hoped to peel away Democratic support for the bill with a 'paycheck protection' amendment that would force labor unions and corporations to get permission from members and shareholders before spending political cash.”).

${ }^{202}$ Thomas B. Edsall, McCain-Feingold Helps GOP; Party Increases Its Fundraising Lead Over Democrats, WASH. Post, Feb. 7, 2004, at A08. 
need to change. ...

$\cdots$

... Yes, I know how to play that fundraising game with the best of them. Only today, I don't sleep nearly as well as I did years ago in those cheap motel rooms or on supporters' sofas. ${ }^{203}$

Implicit in Miller's op-ed is the recognition that, on some level, he enjoys the competitive aspect of raising and spending money. Like fishermen, politicians do not like to admit, publicly or to themselves, that they would like to be restrained from competing against each other in a game of skill, energy, and aggression, even if it detracts from the more important business of legislating and governing. Politicians labor under the same self-serving and selfcongratulatory myths that fishermen do. And yet, at the end of the day, both politicians and fishermen understand on some level that the rat race just gets worse and worse.

In the end, of course, the BCRA passed both the House and Senate and the President signed it into law on March 27, 2002.204 In some ways it was surprising that it took as much effort to pass it as it did, given that the public perceived that campaign spending, especially that procured from soft money, was a corrupting influence. ${ }^{205}$ In fact, campaign finance reform generally receives strong public support, ${ }^{206}$ and the BCRA, as a flashpoint for the issue, enjoyed particularly strong support. ${ }^{207}$ Even if congressional opponents of BCRA really believed that this would not ultimately solve the problem of tainted soft money, why would they be so reluctant to adopt something their constituents so strongly favor? The most plausible answer to this is an irrational fear of the devil they did not know.

While the BCRA is not the tragedy of the commons that I identify

\footnotetext{
203 Zell Miller, A Sorry Way to Win, WASH. Post, Feb. 25, 2001, at B07.

204 See Bipartisan Campaign Reform Act of 2002 (BCRA), Pub. L. No. 107-155, 116 Stat. 81 (codified primarily in scattered sections of 2 and 47 U.S.C.A.) (West 2005)).

${ }^{205}$ Nathaniel Persily \& Kelli Lammie, Perceptions of Corruption and Campaign Finance: When Public Opinion Determines Constitutional Law, 153 U. PA. L. REv. 119, 121, 132-33 (2004).

206 Id. at 143.

207 Public opinion polls vary in quality and results, but almost every stage showed support for the McCain-Feingold legislation. The advocacy group Public Campaign commissioned a reputable polling group, the Mellman Group, to conduct eight statewide polls on support for the bill, and found support ranging from 58 to 75 percent in favor of the McCain-Feingold bill. News Center, Another State of the Union, Another Promise for Campaign Finance Reform? (Jan. 19, 1999), http://www.commondreams.org/pressreleases/jan99/011999e.htm.
} 
in this Article, its close relationship with the campaign spending problem illustrates the pervasiveness of the pathological fears that thwart solutions.

\section{SOLVING TRAGEDIES OF THE COMMONS PROBLEMS}

What, then, is to be done about the true tragedies of the commons that are at the heart of Hardin's contribution? What we have learned from the overfishing problem is that it is very difficult to control overexploitive behavior without addressing the incentives to race. Fishing regulations governing the use of destructive fishing technologies have been fraught with enforcement problems or have been met with technological substitutions that have foiled the conservation purposes behind the regulations. For example, restrictions on boat lengths were met with the entry of rounder and more powerful boats, ${ }^{208}$ while regulations on line lengths were met with lines with more hooks. ${ }^{209}$ Regulations requiring fishing nets to be of a minimum mesh size (to allow small fish to escape) were met with the practice of intertwining nets to reduce the mesh size. ${ }^{210}$ Similarly, seasonal restrictions have only increased the pressure to engage in a short but increasingly intense fishing season. For example, the Alaskan halibut fishery was reduced to a two-day season composed of two 24-hour fishing seasons, ${ }^{211}$ and the Canadian Pacific halibut fishery was reduced to a six-day season. ${ }^{212}$ These absurdly short seasons were simply derbies in which fishermen caught as much halibut as possible, paying no regard to ecological waste or human safety. ${ }^{213}$

The problem is that none of these solutions change the incentive to cheat. Making it more difficult to fish does not change the

208 Comm'n to ReView Individual Fishing Quotas, NAT'L RESEARCH CoUncil, Sharing THE Fish: TOWARD a NATIONAL POLICY ON INDIVIDUAL FISHING QUOTAS 116-17 (1999) [hereinafter SHARING THE FISH].

209 See IUDICELLO ET AL., supra note 187, at 81 (noting that limits on line length are not optimal because they do not address the ways around the length limit that can be used to achieve the same original result, such as adding more hooks on the lines).

${ }^{210} I d$.

211 Id. at 137.

212 Id. at 147.

${ }^{213} I d$. at 137, 147. In derby fisheries such as the Canadian Pacific halibut fishery and the Alaskan halibut fishery before the advent of quota systems, fishermen routinely worked around the clock, elevating risk of injury, while hauling in massive quantities of bycatch-fish species other than halibut incidentally caught—and wastefully discarding them. Id. at 14748. Derby fishing also leaves behind a trail of discarded hooks, lines and nets that continue to "ghost fish" by snaring fish outside of any fishing effort at all. SHARING THE FISH, supra note 208 , at $2-3$. 
fundamental tragedy of the commons dynamics, nor does it change the race to overexploit a rivalrous resource and grab as much as possible while the resource still exists. Indeed, many of these regulatory courses exacerbate the incentives to cheat, overfish, and engage in a race to do so. Of course, sometimes a property rightsbased solution is also unworkable. No matter what the regulatory regime, however, enforcement and monitoring problems must be solved. But the essential failure of regulators in addressing tragedies of the commons is the failure to recognize and address the incentives to race to exploit a finite resource that is rivalrous in consumption.

Like Ackerman and Ayres, I applaud the BCRA because it attempts the difficult task of trying to control excessive campaign behavior rather than throwing up one's hands and declaring defeat. ${ }^{214}$ And the Ackerman and Ayres proposal, a public financing proposal that confers rather than detracts from fundamental liberties, is a salve that could buy some valuable time in terms of removing the taint of campaign money, making political speech more credible.

But in the end, neither of these schemes addresses the incentives of politicians to race to raise money-to try to beat one another even in a game that is "disgusting, degrading, [and] demeaning." 215 Nor would they save the voting public from a world congested with campaign speech. Even "clean" money, if it buys too much speech, will dull the voters' overloaded senses. If in fact we are witnessing a tragedy of the commons in campaign spending, then arresting it will require more than the BCRA and more than what Ackerman and Ayres propose. It will require limitations on the quantity of campaign speech, and thus limits on campaign spending. I am thus arguing for some form of limits to campaign spending.

The argument that we might regulate campaign speech is not as radical or as new as one would suppose. Professor Cass Sunstein argued in Democracy and the Problem of Free Speech that the distinction between campaign contributions and campaign expenditures has turned out to be somewhat illusory. ${ }^{216}$ Moreover, because of the rise of political action committees, the limit on

214 See ACKERMAN \& AYRES, supra note 165, at 177-78 (noting that Senators McCain and Feingold have shown that Americans care about campaign finance reform, an important first step towards meaningful reform).

215 David W. Adamany \& George E. Agree, Political Money: A Strategy for Campaign FINANCING IN AMERICA 8 (1975) (quoting Hubert Humphrey).

${ }^{216}$ Cass R. Sunstein, Democracy and the Problem of Free Speech 95-96 (1993). 
contributions has actually exacerbated some of the problems of corruption and taint that the limit was meant to solve. ${ }^{217}$ Indeed, Sunstein argues that these schemes of half-hearted regulation are no less a regulatory system than one that might involve considerably more governmental involvement, and that replacing it is not necessarily unconstitutional. ${ }^{218}$ More generally, there are those that are concerned with economic power being perpetuated or even amplified by means of protecting free speech rights that, as a practical matter, can only be purchased through large sums of money. ${ }^{219}$ But while these measures have heretofore been justified on the grounds that a new balance must be struck, my argument is different. My argument is that no balancing is necessary because intervention could be beneficial to those that would be regulated.

Exactly what form of campaign expenditure limits might be needed to truly solve the tragedy of the commons in campaign finance and spending is beyond the scope of this Article. It suffices to say, however, that curtailing the incentives to race and overadvertise would almost certainly involve curtailing the quantity of direct appeals from political candidates through the control of their spending. The overabundance of campaign speech, after all, is what causes voters to tune out. As many have suggested, perhaps this curtailment must be coupled with some form of public financing. ${ }^{220}$ We must, after all, attempt to enhance speech and not merely quash it. But limiting candidate access to the public merits serious discussion, especially when we recognize that we already tolerate a number of abridgements, including those set out in the BCRA.

Several U.S. states have enacted various forms of campaign finance reform in an effort to limit influence on elected officials. ${ }^{221}$ Canada has had federal campaign spending limitations in effect

217 Id. at 96-97.

218 Id. at 98-101.

219 OWen M. Fiss, Liberalism Divided: Freedom of SpeEch AND THE MaNy Uses of STATE POWER 10-11 (1996) (stating that the free speech cases of the seventies allowed those with economic power to exert political influence "because they had advanced claims of political liberty that easily fit within the received tradition" and that "[m]oney is speech-just as much as is picketing or selling a book").

${ }_{220}$ See, e.g., sources cited supra note 128 (suggesting that regulation is needed to correct bias towards well-funded groups).

${ }^{221}$ See Michael Saxl \& Maeghan Maloney, The Bipartisan Campaign Reform Act: Unintended Consequences and the Maine Solution, 41 HARV. J. ON LEGIS. 465, 471, 474-76 (2004) (discussing attempts by Maine, Arizona, and Vermont to reduce the influence of special interest groups and campaign contributors on elected officials). 
since 1974. ${ }^{222}$ The Canada Elections Act, ${ }^{223}$ which imposes spending limits on parties $^{224}$ and individual candidates, ${ }^{225}$ provides fairly generous federal subsidies for election expenses, ${ }^{226}$ and requires broadcasters to make primetime air time available for registered political parties. ${ }^{227}$ Interestingly enough, at least one commentator has attributed the spending limits and electoral reforms to "an agreement to put an end to the upward spiral of election spending." 228 The same commentator also noted that

when combined with a reasonable level of public funding, spending limits reduce the pressure for parties and candidates to raise funds. This should not be interpreted to mean that parties face no such pressures. Rather, the pressure to raise money is reduced so that candidates do not find themselves devoting as significant a portion of their time to fundraising as do their American counterparts. By lessening the pressure to raise funds, spending limits are believed to reduce the temptation for parties and candidates to offer a quid-pro-quo for large contributions. ${ }^{229}$

This rosy description of the effects of campaign finance in Canada is a bit challenging to accept wholesale, as the Liberal Party's recent fundraising and "sponsorship" scandal would seem to indicate that quid pro quo rewards for large campaign contributions remained a problem in Canada even with spending limits and public funding. ${ }^{230}$

${ }^{222}$ Election Expenses Act, 1974 S.C. 739, 747, ch. 51, § 13.2 (Can.).

${ }^{223}$ Canada Elections Act, 2000 S.C. 1, ch. 9 (Can.).

${ }^{224} I d$. $\S 422(1)$ (limiting party spending to the product of $\$ 0.62$ times the inflation adjustment factor and the total number of eligible voters in a given district).

${ }^{225}$ Candidates may only spend a calculated amount based upon the number of eligible voters in the district. Id. $\S \S 440-441$.

${ }^{226}$ Parties may receive federal reimbursement for 22.5 percent of their election expenses provided they garner at least two percent of the valid votes nationally, or a total of five percent of the valid votes in districts in which they ran candidates. Id. $\S 435(1)$. Candidates may receive an amount that is equal to $15 \%$ of their election expenses limit provided for in $\S$ 440 , provided that any amount more than $50 \%$ of the candidate's total personal expenses paid by him or her and election expenses paid by his or her official agent is returned to the General Receiver. Id. $\S 464$. Finally, political contributions are eligible for a tax credit worth up to a total credit of $\$ 500$. Income Tax Act, R.S.C. ch. 1, § 127(3) (1985).

${ }^{227}$ The Canada Elections Act requires radio and television stations to provide free primetime air time advertising for registered parties. Canada Elections Act, 2000 S.C. 133134, 140-141, ch. 9, §§ 335, 345 (Can.).

${ }^{228}$ Lisa Young, Regulating Campaign Finance in Canada: Strengths and Weaknesses, 3 ELECTION L.J. 444, 447 (2004).

${ }^{229} I d$. at 450.

${ }^{230}$ See id. at 456. Various officials in the Liberal Party and in the administration of former Liberal Prime Minister Jean Chrétien were accused of awarding government advertising, or "sponsorship" contracts, to firms that made or were coerced into making campaign donations to the Liberal Party. Id. This scandal occurred during a regime of spending limits and public 
Nevertheless, even if the sponsorship scandal resulted in an increase in fundraising by the Liberal Party, the data does not show any significant effect.

In fact, as indicated by Figure 8, campaign expenditures by the major federal parties appear to be flat, whatever the infusion of sponsorship scandal money. ${ }^{231}$ From this perspective the Canadian system appears to have been successful in curbing spending. Data is shown for every year, since parties are always spending money on political activities, but the spikes correspond to years in which federal general elections were held. Data has been adjusted for inflation using the Consumer Price Index for Canada. ${ }^{232}$ I do not translate this data into campaign spending efficiency terms, as I do for the U.S. data, because of the variability of the time between federal general elections. Aggregation of annual data for any particular election would render expenditure figures inconsistent, since the period of aggregation would vary with the period between federal general elections.

funding for candidates. See id. at 444 .

${ }^{231}$ In Canada, a strong party system centers campaign activity upon registered political parties, as opposed to individual candidates. Id. at 445 . Expenses are thus incurred predominantly by parties rather than individual candidates. See, e.g., William T. Stanbury, Financing Federal Politics in Canada in an Era of Reform, in CAMPAIGN AND PARTY FINANCE IN NoRTh AMERICA AND WeStern Europe 68, 92 (Arthur B. Gunlicks ed., 1993) (illustrating much greater "election expenses" than "personal expenses").

${ }^{232}$ See generally Statistics Canada, Table 326-0002, Consumer Price Index, http://cansim2.statcan.ca (last visited Sept. 30, 2005) (providing an online tool to calculate Consumer Price Index based on year and product(s)). 
FIGURE 8

Total Campaign Expenditures in Canada, All Parties (Millions $\$)^{233}$

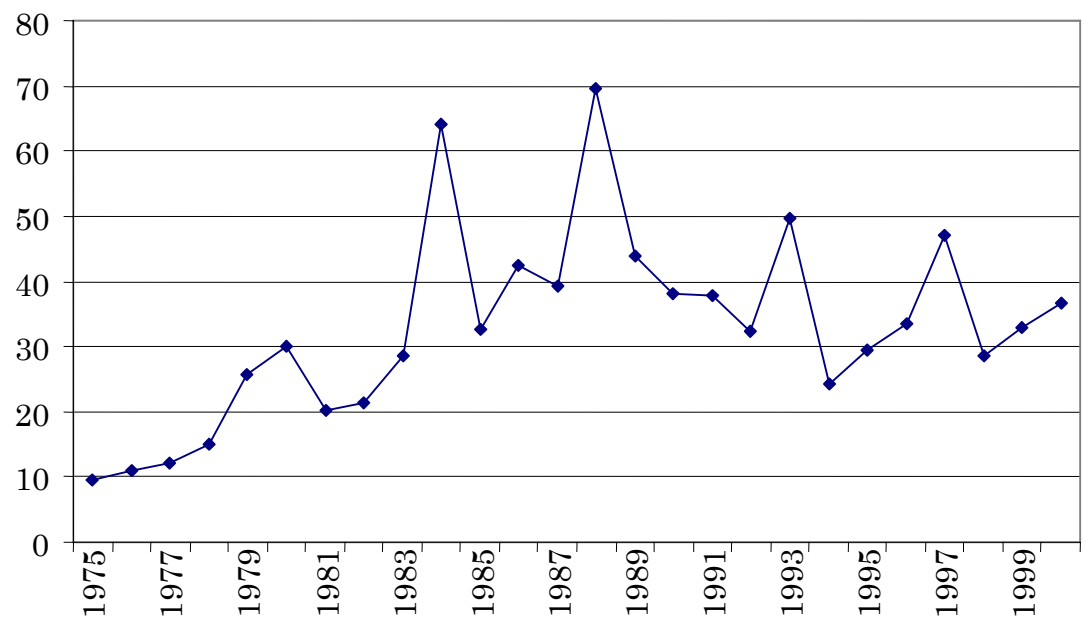

Canada's parliamentary system of government poses different challenges than does the American system. For one thing, federal election periods in Canada are typically thirty-six days, following the issuance of a writ dissolving Parliament and calling for a general election. ${ }^{234}$ This time of intense campaigning limits the period of controversy in a way that lends itself to more solutions than the American system, in which perpetual campaigning is the norm. Limiting speech to thirty-six days every three to five yearsthe typical period between federal elections-seems less offensive than limiting speech in the context of a perpetual American campaign. But the unmistakable lesson from the Canadian experience with spending limits is that the Elections Act has clearly achieved its goal of arresting the rise of campaign spending. No

${ }^{233}$ See William T. Stanbury, Financing Federal Politics in Canada in an Era of Reform, in CAMPAign AND PARTY FinanCE In NORTH AMERICA AND Western EuROPE 68, 74-75 (Arthur B. Gunlicks ed., 1993); Elections Canada On-line, Contributions to Political Parties, http://www.elections.ca/ecFiscals/fiscalmain.asp?objectType=start\&ul=1 (last visited Jan. 9, 2006) (providing information on contributions for 1993, 1997, and 2000 under Table 1: Summaries of Contributions and Expenses).

${ }^{234}$ Canada Elections Act, 2000 S.C. 29, ch. 9, § 57(1) (Can.). The statute specifies a minimum period of thirty-six days, but convention has limited the election period to approximately thirty-six days. See, e.g., Colin Feasby, Issue Advocacy and Third Parties in the United Kingdom and Canada, 48 MCGILL L.J. 11, 45 (2003) ("[A]n election period commences when the prime minister requests that the governor-general dissolve Parliament and issue an election writ and runs for a maximum of thirty-six days until voting."). 
scholarly literature of which I am aware laments the erosion in democratic quality in Canada due to the imposition of spending limits. Other countries with some form of spending limitations include the United Kingdom ${ }^{235}$ and France, ${ }^{236}$ both of which, like Canada, have strong freedom of speech traditions.

Clearly, problems would remain if the U.S. adopted spending limitations. The strongest criticism of campaign spending limits seems to be that any financial prohibitions will only result in inkind behavior. Lott argues that limits on contributions will give rise to in-kind donations. ${ }^{237}$ But is this always such a bad thing? Would it be such a disaster for democracy to have people donating, for example, their time to a political campaign, rather than their money? Perhaps spending limitations would result in candidates spending more time meeting with the public than would otherwise be the case. Again, it is not obvious that this would be a bad thing. Myriad other possibilities exist, but one wonders if the distortions caused by attempts to regulate campaign speech would really be worse than the existing distortions.

\section{CONCLUSION}

Hardin has not "exorcised" the spirit of Adam Smith, but he has engaged the libertarian clarion call for less government and less regulation. While his insights on the imposition of large-group negative externalities are not particularly unique-Pigou understood and articulated this decades earlier ${ }^{238}$-Hardin's observations on how we soil ourselves is distinctive. It poses a direct challenge not only to Smith and libertarian pundits, but also to a strong intellectual tradition of individual liberalism in law. After Hardin, we could no longer take for granted that the individual was the best advocate of her own interests.

${ }^{235}$ R.J. Johnston \& C.J. Pattie, Great Britain: Twentieth Century Parties Operating Under Nineteenth Century Regulations, in CAMPAIGN AND PARTY FINANCE IN NORTH AMERICA AND WESTERN EUROPE 123, 130-31 (Arthur B. Gunlicks ed., 1993).

${ }_{236}$ Thomas Drysch, The New French System of Political Finance, in CAMPAIGN AND PARTY Finance in North America AND Western Europe 155, 165-66 (Arthur B. Gunlicks ed., 1993).

${ }^{237}$ Lott, supra note 157 , at 362.

238 A.C. Pigou, The ECONOMics of Welfare 131-33 (1952) (noting that the value of marginal private product and the value of marginal social net product can be flows from competing employment of a given quantity of resources). In The Economics of Welfare, English economist Alfred Pigou developed the idea that taxes should be imposed to equalize the marginal private costs and marginal social costs of an activity which produces negative externalities. Id. at 192, 195. 
This irony animates a number of public policy problems, in large part because our libertarian culture has made us so obsessed with defending our liberties that we forget to think about our welfare. In this Article, I argue that the problem of uncontrolled campaign spending is one such example. I do not set forth a Constitutional justification for campaign fundraising limits or spending limits. ${ }^{239}$ Despite my praise for the BCRA, it does not purport to solve the problem of controlling third party expenditures, or even acknowledge that a solution exists. I address only direct federal campaign spending. In the end, if the Constitutional value that we are protecting when we strike down these limits is freedom of speech, then we must confront threats to that freedom. This Article is meant to demonstrate that one threat to that freedom is the excessive exercise of the freedom itself. Well-recognized intrusions upon the right to speak are based upon a recognition of competing interests. My proposed curtailment of speech is motivated by protection of the right to speak itself. While great care must be taken to design a regulatory scheme and implement rules that minimize perverse incentives, no balancing of interests is necessary.

It is curious that we have this dichotomy between speech and property. Why does the Constitution treat property regulation and speech regulation differently? Is it because we believe property is "scarce" and speech is "free"? This is clearly not true in a modern, information-overloaded society. I certainly do not advocate jurisprudentially collapsing speech and property, but it is worth bearing property lessons in mind as we think about campaign speech and about speech generally. Just as the tragedy of the commons has taught us that in a property context we sometimes cannot trust people alone to order their affairs in a sensible way, we should now realize that some paternalism in the speech context may be necessary as well. Because political campaign speech is so important to a well-functioning democracy, it is all the more important that we consider bringing it into the regulatory realm, and not leaving it to chimerical free market ideals.

239 But see Blasi, supra note 137, at 1283 (arguing that candidates who devote themselves to round-the-clock fundraising implicate the Republican Form of Government Clause of Article I and the Seventeenth Amendment). 